\title{
A synopsis of Galianthe (Rubiaceae) in Rio Grande do Sul, Southern Brazil, and a new endemic species from Serra Geral
}

\author{
Javier Elías Florentín ${ }^{*}$, Mariela Nuñez Florentin ${ }^{1}$ and Elsa Leonor Cabral ${ }^{1}$
}

Received: April 12, 2017

Accepted: June 19, 2017

\begin{abstract}
Thirteen species of the genus Galianthe have been recorded for state of Rio Grande do Sul, Brazil. The species are distributed among seven biomes, one of which contains all thirteen taxa-Subtropical Seasonal Forest. Herein a new endemic species, G. riograndensis J. Florentín \& E.L. Cabral, is described, illustrated and differentiated from all other species of the genus by having 3-4 verticillate leaves and a long bifid style. In addition, the pollen grain morphology and the seed micromorphology of the new species are described and illustrated, and the conservation status assessed according to IUCN criteria. Moreover, G. chodatiana is recorded for the first time from the state, and a lectotype for G. equisetoides is designated. Most of the species of Galianthe are described and illustrated with detailed photos of living specimens. A taxonomic key for species identification, as well as comments on distribution, overall phenology and habitat, are also presented. The distribution of the new species is discussed in the context of the biogeographic region of the state, and maps and a table of species by biome are also provided.
\end{abstract}

Keywords: Galianthe, Rubioideae, Southern Brazil, Spermacoceae, taxonomy.

\section{Introduction}

Recent molecular phylogenetic studies have demonstrated that Galianthe (Rubiaceae) belongs to the Spermacoce clade (Kårehed et al. 2008; Salas et al. 2015), is monophyletic and is most closely relate to Carajasia and Schwendenera, with both sharing the presence of pollen grains with a double reticulum (Salas et al. 2015). The genus is Neotropical, with the exception of a single taxon living in Mesoamerica (G.brasiliensis subsp. angulata), is widespread in South America (Cabral \& Bacigalupo 1997; Cabral 2009), with the majority of species occurring in Brazil (37 species). The species occur in campos rupestres (quartzitic rock outcrops), cerrado (savanna), low land grasslands, campos de altitude (highland grasslands), caatinga vegetation (seasonaly dry tropical forests) and savanna hillsides; in lateritic, sandy soils or with rock outcrops. Exceptionally, there are some shade-loving species, which occur in the understory of forests and woodlands, such as G. hispidula, G. brasiliensis, and G. laxa (Cabral \& Bacigalupo 1997; Cabral 2009; Cabral \& Salas 2015; Carmo et al. 2016). Galianthe comprises 50 species grouped in two subgenera: Galianthe subg. Galianthe, with 40 species, and Galianthe subg. Ebelia, with 10 species (Cabral \& Bacigalupo 1997; Cabral 2009). In floristic surveys of Rio Grande do Sul, Rambo (1962) and Porto et al. (1977) recorded 10 and 7 species of Galianthe, respectively, for the state, under Borreria and Diodia, generic names linked to Galianthe based principally on fruit dehiscence. Galianthe differs from the remaining genera of the Spermacoce clade by having an erect habit generally with xylopodium, distylous flowers arranged in lax thyrsoid inflorescences, plump or

\footnotetext{
${ }^{1}$ Instituto de Botánica del Nordeste (CONICET-UNNE), Sargento Cabral 2131, cc. 209, P.O. Box. 3400. Corrientes, Argentina

* Corresponding author: florentinjaviere@gmail.com
} 
complanate seeds with wing-like margins, pollen with a double reticulum, and a basic chromosome number of $\mathrm{x}=8$ (Cabral 2009).

Since new data regarding this genus has become available for Rio Grande do Sul, and because previous taxonomic revisions and regional checklists have become outdated (Rambo 1962; Porto et al. 1977; Cabral 2002), an updated taxonomy of Galianthe is needed.

As a result of taxonomic studies of the tribe Spermacoceae for the Flora do Brasil 2020, a new species, Galianthe riograndensis, was recognized. Therefore, the aims of the present study are to: present an illustrated morphological description and a conservation assessment for the new taxa. The new species is also included in an identification key for all species of Galianthe recorded in the state of Rio Grande do Sul, along with maps, tables, and comments about the geographic distribution and habitats of the species.

\section{Materials and methods}

Descriptions were made by analyzing live specimens and herbarium material from the collections deposited at the herbaria B, BR, CRI, CTBS, CTES, EAC, FLOR, FUEFS, FUEL, FURB, HAS, HBR, HDCF, HPL, HUCS, HVAT, IAC, IBGE, ICN, INPA, JOI, K, LIL, MBM, MO, MPUC, MVFA, NY, P, PACA, R, RB, SI, SP, UB, UEC [acronyms according to Thiers (2017)]. Additionally, databases of Lista de Espécies da Flora do Brasil and Missouri Botanical Garden were consulted. Distribution, habitat, details of flower or fruits, and phenological data were recorded from specimen labels and field observations. In order to illustrate features or structures not or poorly shown in previous literature, a detailed photographic record of diagnostic vegetative and floral features was made (except for Galianthe riograndensis J. Florentín \& E.L. Cabral and G. verbenoides (Cham. \& Schltdl.) Griseb.). Vegetative and reproductive characters were measured on living and pressed specimens using a digital caliper. To analyze the distribution of species by biome, specimens were georeferenced using Google Earth (2015) and plotted in DIVA-GIS (Hijmans 2013). We followed the classification of the vegetation of Southern Brazil proposed by Iganci et al. (2011), who modified the classification of Leite (2002).

Pollen grains of Galianthe riograndensis were acetolyzed according to Erdtman (1966) and mounted in glycerine jelly for analysis by light microscopy (LM). Conventional parameters $(\mathrm{P}=$ polar axis, $\mathrm{E}=$ equatorial axis) of at least 20 grains were measured under LM, and the exine was analyzed using scanning electron microscopy (SEM). Seeds were also analyzed using SEM. For SEM analyses, seeds and acetolyzed pollen grains were sputter-coated with gold, and then photographed with a Jeol 5800 LV SEM (scanning electron microscopy service of the SGCyT-UNNE, Corrientes, Argentina). Pollen terminology follows Punt et al. (2007) and seed terminology follows Stearn (1986).
Conservation status was assessed according to IUCN criteria (2001). The extent of occurrence (EOO) and the area of occupancy (AOO) were estimated using GeoCAT (Bachman et al. 2011).

\section{Results and discussion}

\section{Taxonomic treatment}

Galianthe Griseb., Symb. Fl. Argent. 24: 156. 1879. Type: Galianthe fastigiata Griseb. (For synonymy and commentaries about the types see Cabral \& Bacigalupo 1997).

Subshrubs, erect or decumbent, exceptionally scandent, with or without xylopodium; stems winged or not, glabrous or pubescent. Stipular sheath with 1-multifimbriate margin, covering part of the internode above the corresponding leaf pair or at the same level of the leaf pair. Leaves opposite, frequently pseudo-verticillate, sessile; leaf blades entire, chartaceous or coriaceous. Inflorescences thyrsoid, cymose or partial inflorescences in dichasium more or less condensed, fascicles or heads; in the main and/or secondary branches. Flowers 4-merous, actinomorphic, distylous, the short-styled flowers (SS flowers) slightly larger than the long-styled flowers (LS flowers); calyx 4-lobated, rarely 2, with intercalary teeth between lobes, sometimes colletertipped; corolla infundibuliform or campanulate, white, exceptionally pale pink or lilac, internally with moniliform hairs with the same or different arrangement between both floral morphs; stamens 4, filaments of variable length in SS flowers and LS flowers, anthers dorsifixed; nectariferous disk entire or 2-lobed; ovary 2-locular, each locule 1-ovulate; style with bifid stigma. Capsule septicidal with dehiscent or indehiscent valves. Seeds plump or dorsoventrally flattened, winged, with strophiole on the ventral face, persistent or caducous.

\section{Distribution of species}

Regions of greatest concentration, diversification and endemism of species of Galianthe are in Brazil, especially in the Brazilian cerrado, with 37 taxa, 21 of which are endemic (Cabral 2002; Flora do Brasil 2020). In the state of Rio Grande do Sul there are 13 species of which only one is endemic. The species described herein, G. riograndensis, is from the Reserve "Ibicuí-Mirim" in Santa Maria. Some species occur in restricted areas of the Southern Region of the country, such as G. latistipula (states of Rio Grande do Sul and Santa Catarina), and G. verbenoides and G. chodatiana (states of Rio Grande do Sul, Santa Catarina and Paraná), while the remaining species have wider distributions.

According to phytoecological studies of Southern Brazil, Leite (2002) recognized ten different phytoecological units and three transitional vegetation areas based on geology, terrain, climate, and soil. Iganci et al. (2011) modified the 
classification of Leite (2002), and recognized nine biomes, of which seven occur in the state of Rio Grande do Sul: Tropical Forest (TRF), Tropical Coastal Scrub (TCS), Subtropical Seasonal Forest (SSF), Subtropical Mixed Forest (SMF), Subtropical Highland Grasslands (SHG, synonymous with Campos de Cima da Serra), Temperate Shrubland (TES) and Low Altitude Temperate Grasslands (LTG). The 13 species of Galianthe from Rio Grande do Sul (Fig. 1A-B, Tab. 1), inhabit the Subtropical Seasonal Forest (SSF) and share other biomes, except for Galianthe riograndensis which has been recorded only in SSF (Fig. 1B). According to Leite (2002), these forests are characterized by possessing a climate of with two seasons, which differ markedly in temperature: one season (summer) of up to 5 months with an average temperature above $20^{\circ} \mathrm{C}$, and the other season (winter) of up to two months with an average temperature below $15^{\circ} \mathrm{C}$. The seasonal forests exhibit varying structure that can be grouped into four strata. The first stratum is composed of tall and emergent trees, while the second is composed of dense trees of uniform height. In spring and summer, these upper strata are covered by dense foliage, which is lost during the winter season, giving to the forests a deciduous appearance. The third stratum is composed of young trees and the fourth is characterized by having more or less densely distributed shrubs. Species of Galianthe have a greater representation in this latter stratum, and especially in more open areas and forest edges.

\section{New species}

Galianthe riograndensis J. Florentín \& E.L. Cabral sp. nov. Type: Brazil. Rio Grande do Sul: Campo dos Barcelos, 8 December 1990, N. Silveira 7963 (Holotype HAS!; Isotype CTES!) (Figs. 2-3).

Galianthe riograndensis is similar to G. equisetoides in having stems constricted at nodes, elliptic leaves, and plump seeds, but differs in having 3-4 verticillate leaves, without brachyblasts, elliptic or narrowly elliptic leaf blades with 2-3 secondary veins [vs. 2 (-3) pseudoverticillate leaves, with axillary brachyblasts, linear or filiform leaf blades with inconspicuous secondary veins]; corolla on SS flowers 8.5-10 $\mathrm{mm}$ long, and LS flowers 8.5-9.6 mm long, internally with a fringe of moniliform hairs distributed from the middle of the corolla tube to the lower half of the corolla lobes, and a long bifid style (vs. corolla 4.5-6 mm long, corolla only with a ring of moniliform hairs in the corolla tube, style not divided) (Tab. 2).

Subshrubs erect, 0.6-1.5 m tall, with xylopodium; 2-3 stems per plant, simple, cylindrical to subtetragonal, fistulose, glabrous, constricted at nodes, without brachyblasts, internodes 9-15 cm long. Stipular sheath 9-14 mm long, glabrous, with 3-6 fimbriae; fimbriae 5-7 mm long. Leaves (3) 4 verticillate, sessile, leaf blades elliptic or narrowly elliptic, $30-100 \times 7-13 \mathrm{~mm}$, base acute, apex attenuate and margin revolute, coriaceous, glabrous, discolorous, with 2-3 pairs of secondary veins visible on the abaxial surface. Inflorescences thyrsoid, terminal. Flowers with hypanthium 1.5-2 mm long, glabrous; calyx 4-lobed, lobes 1-1.5 mm long, triangular, glabrous, intercalar colleters; corolla infundibuliform, white or pale lilac, floral bud lilac or pink, externally papillose, internally with fringe of moniliform hairs distributed from middle of corolla tube to lower half of corolla lobes; SS flower with corolla 8.5-10 $\mathrm{mm}$ long, corolla lobes 3-5 mm long; stamens exerted, filaments 3-3.5 mm long, anthers 1.5-2.5 mm long; style 4.5-5 mm long, deeply divided, stigma 3-4 $\mathrm{mm}$ long, bifid, filiform, papillate. LS flower with corolla 8.5-9.6 mm long, corolla lobes $3.4-4.8 \mathrm{~mm}$ long; filaments $1 \mathrm{~mm}$ long, anthers 1.55-2 mm long; style 8.5-9.5 mm long, deeply divided, stigma $2.8-3.5 \mathrm{~mm}$ long, filiform, papillate. Nectariferous disk entire. Capsule 4.5-6 mm long, subcylindrical, glabrous, with dehiscent valves. Seeds 3-3.5 mm long, subcylindrical, dark brown, dorsal surface convex, ventral surface \pm flat, with a longitudinal groove partially covered by a caducous strophiole; testa reticulate-foveate, cells polygonal or nearly circular, $55-110 \mu \mathrm{m}$ wide, anticlinal walls straight, periclinal walls concave.

Pollen morphology: Pollen grains 8-9 zonocolporate (SS flowers), 7-8 zonocolporate (LS flowers), mediumsized, pollen of SS flowers larger than that of LS flowers (SS flowers: $\mathrm{P}=44.1-48.8 \mu \mathrm{m}$, and $\mathrm{E}=46.4-51.6 \mu \mathrm{m}$; LS flowers: $\mathrm{P}=40.1-44.4 \mu \mathrm{m}$ and $\mathrm{E}=43.3-46.6 \mu \mathrm{m})$. Oblate spheroidal $(\mathrm{P} / \mathrm{E}=0.91-0.96)$, outline circular in polar view. Ectocolpus 22.3-28.3 $\mu \mathrm{m}$ long. Endoporus 4.9-7.2 $\mu \mathrm{m}$ long. Exine 3.7-5.5 $\mu \mathrm{m}$ thick, semitectate-bireticulate. Infrareticulum complete, nanogranulate; suprareticulum complete, muri mostly psilate; muri 0.3-0.5 $\mu \mathrm{m}$, lumina $0.8-1.8 \mu \mathrm{m}$.

Distribution, habitat, and phenology: Galianthe riograndensis is known only from "Reserva Biológica do Ibicuí Mirim", located on the border between the municipalities of São Martinho da Serra and Itaara, in the southern region of Serra Geral, in the southern highlands of Brazil (state of Rio Grande do Sul). This species inhabits the geographic center of the state in an ecotonal region composed of hillsides with basaltic rocky fields and seasonal forest. Flowering occurs from October to February, and fruiting from March to June.

Observation: The specimen M. L. Abruzzi 1644, included as paratype of this species, was incorrectly designated by Cabral (2009) as a neotype of Galianthe equisetoides (Cham. \& Schltdl.) E.L. Cabral.

Etymology: The epithet "riograndensis" refers to the distribution of the species in the state of Rio Grande do Sul and to it being endemic to the state.

Conservation status: According to IUCN criteria (IUCN 2012) Galianthe riograndensis should be classified as endangered [EN B2ab(ii, iii)]. The extent of occurrence (EOO) is calculated to be $15237 \mathrm{~km}^{2}$, and the area of 


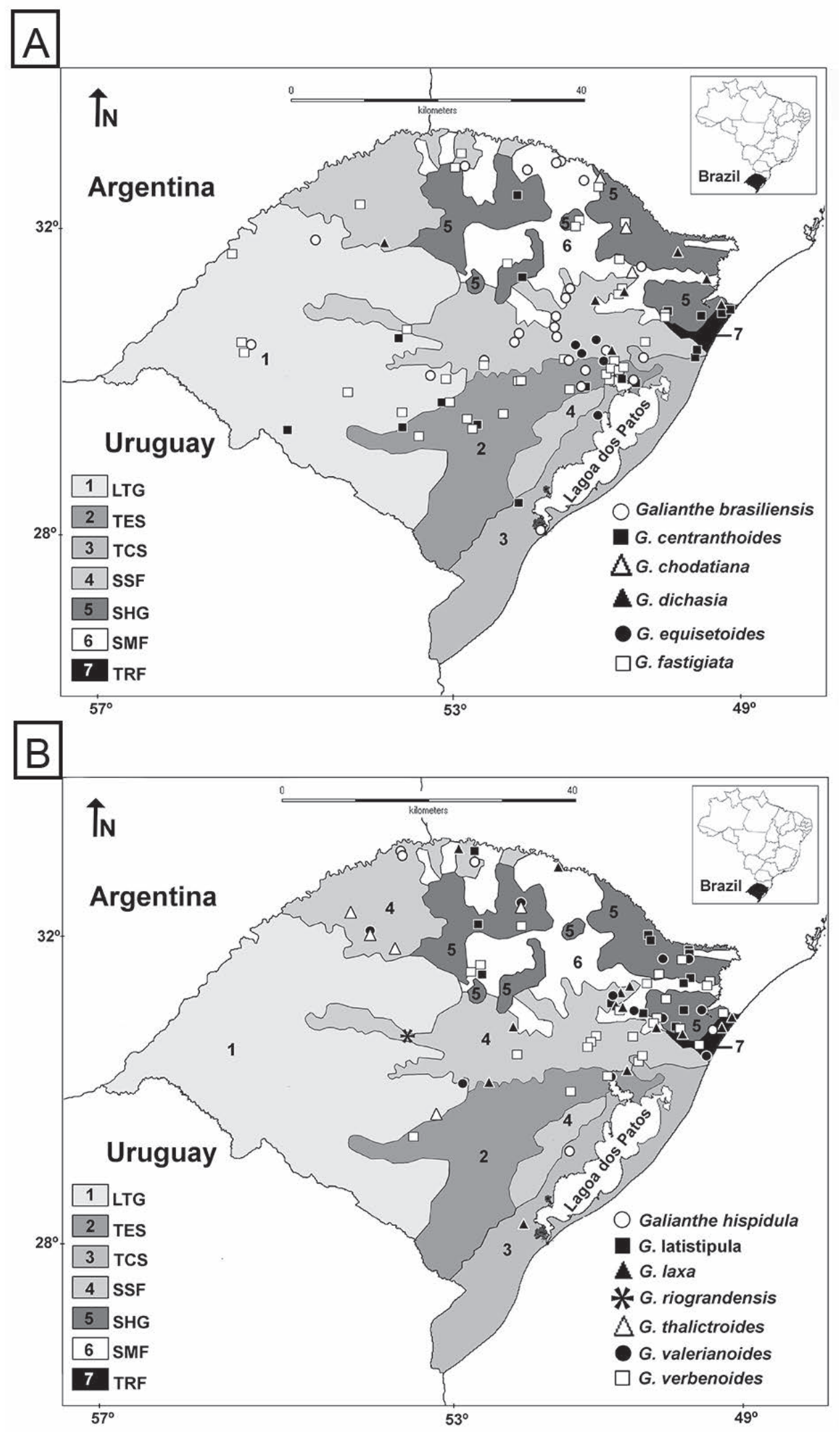

Figure 1. A-B: Map of the distributions of species of Galianthe present in Rio Grande do Sul. 1) Low Altitude Temperate Grasslands (LTG), 2) Temperate Shrubland (TES), 3) Tropical Coastal Scrub (TCS), 4) Subtropical Seasonal Forest (SSF), 5) Subtropical Highland Grasslands (SHG), 6) Subtropical Mixed Forest (SMF) and 7) Tropical Forest (TRF). 
Table 1. Distribution of the species considering the biomes 1) Low Altitude Temperate Grasslands (LTG), 2) Temperate Shrubland (TES), 3) Tropical Coastal Scrub (TCS), 4) Subtropical Seasonal Forest (SSF), 5) Subtropical Highland Grasslands (SHG), 6) Subtropical Mixed Forest (SMF), 7) Tropical Forest (TRF).

\begin{tabular}{|c|c|c|c|c|c|c|c|}
\hline Species & $\operatorname{LTG}(1)$ & TES (2) & $\operatorname{TCS}(3)$ & SSF (4) & SHG (5) & $\operatorname{SMF}(6)$ & $\operatorname{TRF}(7)$ \\
\hline G. brasiliensis & $\mathrm{x}$ & $\mathrm{x}$ & $\mathrm{x}$ & $X$ & & $X$ & \\
\hline G. centranthoides & $\mathrm{X}$ & $\mathrm{x}$ & $\mathrm{x}$ & $\mathrm{X}$ & $\mathrm{X}$ & & $\mathrm{X}$ \\
\hline G. chodatiana & & & & $\mathrm{X}$ & $\mathrm{X}$ & $\mathrm{X}$ & \\
\hline G. dichasia & & & & $\mathrm{X}$ & $\mathrm{X}$ & $\mathrm{x}$ & $\mathrm{X}$ \\
\hline G. equisetoides & & $\mathrm{x}$ & $\mathrm{x}$ & $\mathrm{x}$ & & & \\
\hline G. fastigiata & $\mathrm{X}$ & $\mathrm{x}$ & & $\mathrm{x}$ & $\mathrm{X}$ & $\mathrm{X}$ & \\
\hline G. hispidula & & & $\mathrm{x}$ & $\mathrm{X}$ & & & $\mathrm{X}$ \\
\hline G. latistipula & & & & $\mathrm{x}$ & $\mathrm{X}$ & $\mathrm{x}$ & \\
\hline G. laxa subsp. laxa & & $\mathrm{x}$ & $\mathrm{x}$ & $\mathrm{X}$ & $\mathrm{X}$ & $\mathrm{X}$ & $\mathrm{X}$ \\
\hline G. riograndensis & & & & $\mathrm{X}$ & & & \\
\hline G. thalictroides & $\mathrm{X}$ & & & $\mathrm{X}$ & $\mathrm{X}$ & & \\
\hline G. valerianoides & $\mathrm{X}$ & $\mathrm{x}$ & & $\mathrm{x}$ & $\mathrm{X}$ & $\mathrm{X}$ & $\mathrm{X}$ \\
\hline G. verbenoides & & $\mathrm{x}$ & $\mathrm{x}$ & $\mathrm{X}$ & $\mathrm{X}$ & $\mathrm{X}$ & $\mathrm{X}$ \\
\hline Total of species per biomes & 5 & 7 & 6 & 13 & 9 & 8 & 6 \\
\hline
\end{tabular}

occupancy (AOO) is estimated at $16000 \mathrm{~km}^{2}$ (cell size $2 \mathrm{~km}$ ). The species is known from four collections representing one locality within the state of Rio Grande do Sul.

Paratypes: Rio Grande do Sul: Santa Maria, Reserva
Biológica do Ibicuí-Mirim; Barragem de Saturnino, 9 November 1988, N. Silveira 5929 (CTES, HAS); Campo dos Barcelos, 9 November 1988, M.L. Abruzzi 1644 (CTES, HAS); idem, 19 June 1991, N. Silveira 11047 (HAS).

\section{Key to species of the genus Galianthe native to Rio Grande do Sul, Southern Brazil}

1. Habit erect or scandent; stems never winged; fruit with dehiscent valves

1'. Habit erect or decumbent; stems frequently winged; fruit with indehiscent valves .......................................... 11

2. Stems with xylopodium; inflorescences only on the main stems ............................................................. 3

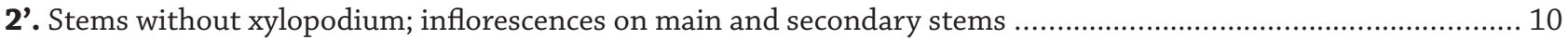

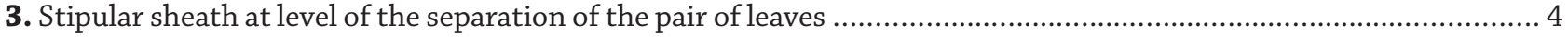

3'. Stipular sheath extended over the separation of the pair of leaves ............................................................... 8

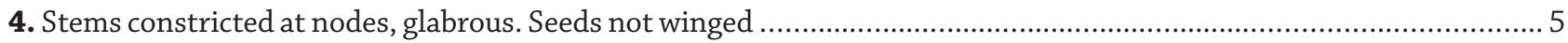

4'. Stems not constricted at nodes, pubescent or glabrous. Seeds winged ..................................................... 6

5. Stipular sheath 3.8-4.7 mm long; leaves 2-3 pseudoverticillate, with inconspicuous secondary veins; corolla white; LS corolla 4.5-5 mm long; SS corolla flower 5-6 mm .............................................................. G. equisetoides 5'. Stipular sheath 9-14 mm long; leaves (3) 4 verticillate, with 2-3 conspicuous secondary veins; corolla pale lilac or pinkish; LS corolla 8.5-9.6 mm long; SS corolla 8.5-10 mm long

G. riograndensis

6. Stems and leaves glabrous or papillate; leafblade $0.2-4 \mathrm{~mm}$ wide, with secondary veins inconspicuous; nectariferous disk entire

G. thalictroides

6'. Stems and leaves pubescent or pilose; leafblade 3-28 mm wide, with conspicuous secondary veins; nectariferous disk bilobate

G. valerianoides

7. Plants $0.8-2.5 \mathrm{~m}$ tall; stems angles with retrorse hairs; stems, leaves, flowers, and fruits pilose

7'. Plants 0.35-1 m tall; stems angles without retrorse hairs; stems, leaves, flowers, and fruits pubescent

G. centranthoides

8. Stem glabrous; leaves opposite, without axillary brachyblasts and basal leaves in rosette; seeds not winged

8'. Stem glabrous or with scattered and retrorse hairs; leaves pseudoverticillate by the presence of axillary leafy brachyblasts; basal leaves never in rosette; winged seeds ....

9. Stem single, glabrous; leaves glabrous; stipular sheath prolonged above the separation of the pair of leaves, 5-7 mm long, glabrous, with irregular margin with a remarkable central fimbria, triangular, acuminate, and shorter lateral fimbriae G. latistipula 
9'. Stems with lateral branches with scattered hairs; leaves pubescent; stipular sheath with a brief prolongation above the separation of the pair of leaves, 3-5 mm long, pilose or pubescent, with 6-7 fimbriae of equal length

G. chodatiana

10. Abaxial surface of leaf-blade with visible papillae with thick bases on veins; LS corolla internally with a ring of short hairs in the middle of the corolla tube.... G. verbenoides

10'. Abaxial surface of leaf-blade without visible papillae; LS corolla internally with a ring of slender short hairs in the middle of the corolla tube, and thick long hairs in the middle of the corolla lobes ..... G. laxa

11. Leaves with only the primary vein visible G. brasiliensis

11'. Leaves with the secondary veins furrowed on the adaxial surface and marked on the abaxial surface

12. Stems decumbent, stoloniferous; inflorescence with partial inflorescences pauciflorous, fasciculate G. hispidula 12'. Stems erect, without stolons; inflorescence with partial inflorescences multiflorous, subglomeriform and condensed G. dichasia

Galianthe brasiliensis (Spreng.) E.L. Cabral \& Bacigalupo, Ann. Missouri Bot. Gard. 84(4): 861-865. 1997. Fig. 4A-F

(For synonymy and commentaries about the types see Cabral \& Bacigalupo 1997).

Shrub erect, branched, $0.25-1.5 \mathrm{~m}$ tall, with xylopodium; stems tetragonal, angles narrowly winged. Stipular sheath hispidulous, with 5-7 fimbriae. Leaves frequently pseudoverticillate, leaf blades elliptic or obovate, 3-35 $\times$ 0.7-11 mm, middle vein glabrous on the adaxial surface and scabridulous on the abaxial surface, with only primary nerve visible. Inflorescences thryrsoid-spiciform, with floral node of fasciculate flowers of main and secondary branches. Flowers shortly pedicellate; hypanthium turbinate, hispidulous; calyx 4-lobed, with 2 large lobes; corolla internally with ring of moniliform hairs. LS flower with corolla 1.9-2.2 mm long. SS flower with corolla $2.7 \mathrm{~mm}$ long. Capsule 1.5 (2.5) $\mathrm{mm}$ long, turbinate, dorsoventrally compressed, hispidulous, with indehiscent valves. Seeds 1.8-2 mm long, ventral face with a small strophiole; testa reticulate.

Distribution, habitat, and phenology: Brazil (BA, MG, PR, RJ, RS, SC, and SP), Paraguay, Uruguay, and Argentina. This species grows in low grasslands, margins of rivers and streams, and edges and interiors of forests. Flowering and fruiting throughout the year.

Specimens examined: Rio Grande do Sul: Arroio dos Ratos, December 1973, P. Mariath 150 (CTES); Alegrete, Río Ibira Puitan, 13 March 1948, M. Palacios-Cuezzo 1829 (CTES); Bom Retiro do Sul, Pedreira, 3 April 2014, G. B. Scherer s/n. (HVAT); Cachoeira do Sul, 19 February 1948, M. Palacios Cuezzo 1068 (CTES); Caxias do Sul, Criúva, Cascata da Mulada, 28 June 2015, F. Gonzatti 1935 (HUCS); Caxias do Sul, Cascata da Mulada, Criúva, 28 June 2015, F. Gonzatti 1935 (FURB, HUCS); Colinas, 18 January 2013, A. M. Pavan, $s / n$ (HVAT); Erechim, Parque Longines Malinowski, 6 November 1995, A. Butzke 819 (HUCS); Estrela, Linha Arroio do Ouro, 23 March 2013, M. Teixeira s/n (HVAT); Guaíba, Bairro Passopetim, 1985, K. Mizoguchi 2344 (MO); Lajeado, Bairro Carneiros, Campus Univates, margem do Rio T, 1 April 2013, E. Freitas 909 (HVAT); Liberato Salzano,
Pinhalzinho, 13 April 1997, T. M. Pedersen 16310 (NY); Marcelino Ramos, Barranca do Rio Uruguai, 23 September 1987, J.A. Jarenkow 722 (FLOR); Marcelino Ramos Estreito Augusto César, 8 October 1987, R. M. Klein 12242 (NY); Montenegro, Perecí, 31 March 1950, B. Rambo 46526 (K, SP); Montenegro, 26 November 1950, B. Rambo 49240 (IAC); Muçum, Linha Barra das Contas, Mata Ciliar do Rio Taquari, 7 January 2014, G. Nicolini s/n (HVAT); Pelotas, 10 March 1958, J. da Costa Sacco 955 (NY); Porto Alegre, Morro do Côco, 20 June 1973, J. Lindeman et al. s/n. (CTES, ICN); idem, 21 April 1974, M. L. Porto 595 (CTES); Santa Cruz do Sul, Picada Quilombo, December 1926, C. Jürgens 212 (HUCS); São Jerônimo, Pólo Carboquímico,18 October 1982, R. L. Dutra 76 (UEC); São José do Ouro, RS-343, 5 km Barracão, 29 December 1997, J. A. Jarenkow 3739 (FLOR); São Leopoldo, s.d., R. Reitz s/ $n$ (NY); São Leopoldo, October 1940, J. Eugenio 1839 (SP); Sao Leopoldo, 1940, J. E. Leite 397 (NY); São Luís, estrada para Santiago, RS-168, Km 74, 27 February 2010, E. Melo 7830 (HUEFS); Sao Sepe, 22 February 1948, M. Palacios-Cuezzo 1555 (CTES); São Vicente do Sul, Fazenda Santa Fé, December 1981, O. Bueno 3387 (HAS); Roca Sales, Linha Bento Gonçalves, 17 June 2013, P. Zampol s/n (HVAT); Roca Sales, Linha Fernando Abott, Mata Ciliar do Rio Taquari, 17 December 2013, M. Teixeira s/n (HVAT). Taquari, Passo da Aldeia, margem do Rio Taquari, 22 January 2013, E. Freitas 902 (HVAT).

Galianthe centranthoides (Cham. \& Schltdl.) E.L. Cabral, Bol. Soc. Argent. Bot. 273 (3-4): 240. 1991. Fig. 4G-L

(For synonymy and commentaries about the types see Cabral 2009)

Subshrub erect, $0.35-1 \mathrm{~m}$ tall, with several main branches and secondary developed branches, voluminous xylopodium; stems subtetragonal to tetragonal, pubescent. Stipular sheath densely pubescent, with 5-7 fimbriae, glabrescent or pubescent. Leaves pseudoverticillate, with leafy brachyblasts, leaf blades elliptic, oblong or narrowly elliptic, 30-55 (-70) × 3-12 (-28) mm, pubescent, plicatenervose, with 4-6 pairs of visible secondary and tertiary veins. Inflorescences thyrse corymbiform, terminal only on 


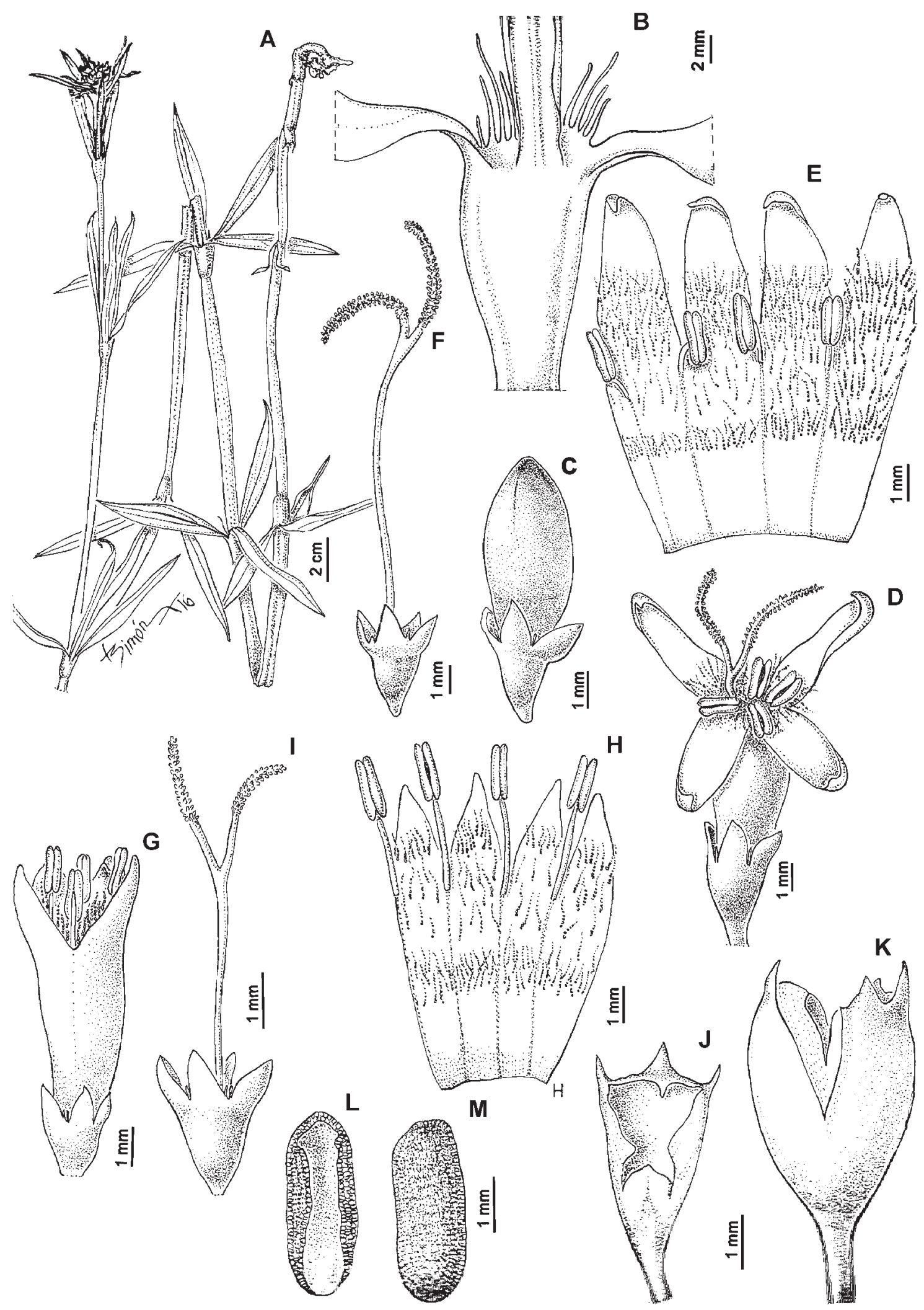

Figure 2. Galianthe riograndensis. A: Habit. B: Detail of stipular sheath. C: Floral bud. D-F: Short-styled flower (Abruzii 1644). D: Flower. E: Opened corolla. F: Hypanthium, calyx, style and stigma. G-I: Long-styled flower (Silveira 5929). G: Flower. H: Opened corolla. I: Hypanthium, calyx, style and stigma. J: Valve, ventral view. K: Fruit. L: Seed, ventral surface. M: Seed, dorsal surface. (Drawn by Laura Simón) 

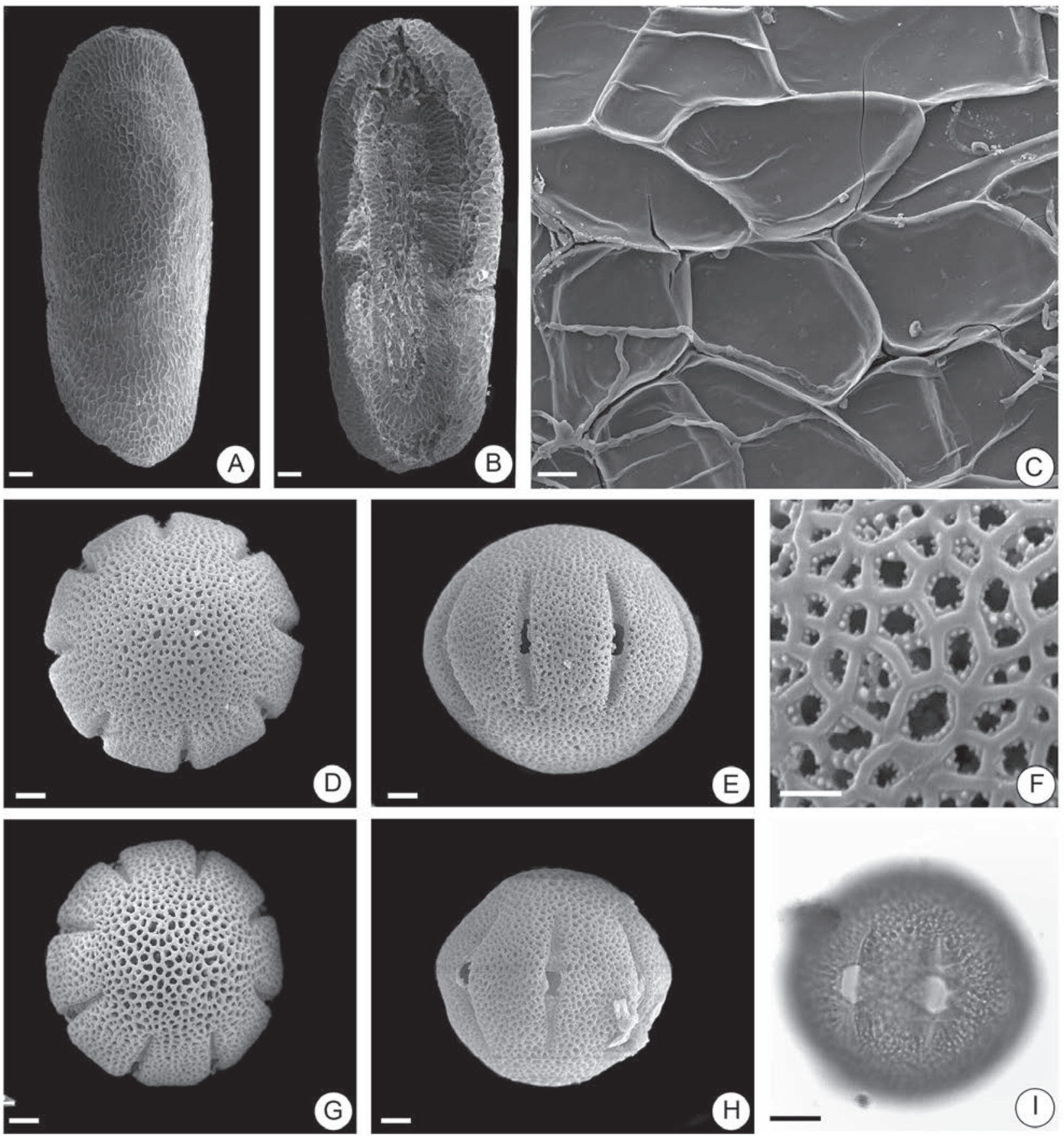

Figure 3. Galianthe riograndensis. SEM photomicrographs of seeds and pollen. A: Ventral surface of seed. B: Dorsal surface of seed. C: Detail of the testa surface. D: Polar view of pollen grain (SS flower). E: Equatorial view of pollen grain (SS flower). F: Detail of the exine. G: Polar view of pollen grain (LS flower). H: Equatorial view of pollen grain (LS flower). I: Pollen morphology (equatorial view) in LM.

main branches, long pedunculate; axes and bracts pubescent. Flowers with turbinate hypanthium with antrorse hairs; calyx 4-lobed, lobes pubescent with intercalar colleters; corolla externally pubescent and internally with dense moniliform hairs, thin in corolla tube and thick in corolla lobes; SS flower with corolla 5.5-6.5 mm long; LS flower with corolla 4.5-6 mm long. Capsule 4-6.5 mm long, pubescent, with dehiscent valves. Seeds $4.5-5 \mathrm{~mm}$ long, dorsoventrally compressed, winged, ventral face covered by caducous flat strophiole.

Distribution, habitat, and phenology: Brazil (GO, MG, PR, RS, SC, and SP), eastern Paraguay, Uruguay, and Argentina. It grows in disturbed places, on roadsides and preferably in sandy soils. Flowering from September to December, and fruiting from January to May.

Observations: Galianthe centranthoides varies in size and morphology of leaves, and density of pubescence of the whole plant, characters that lead to misidentification of 

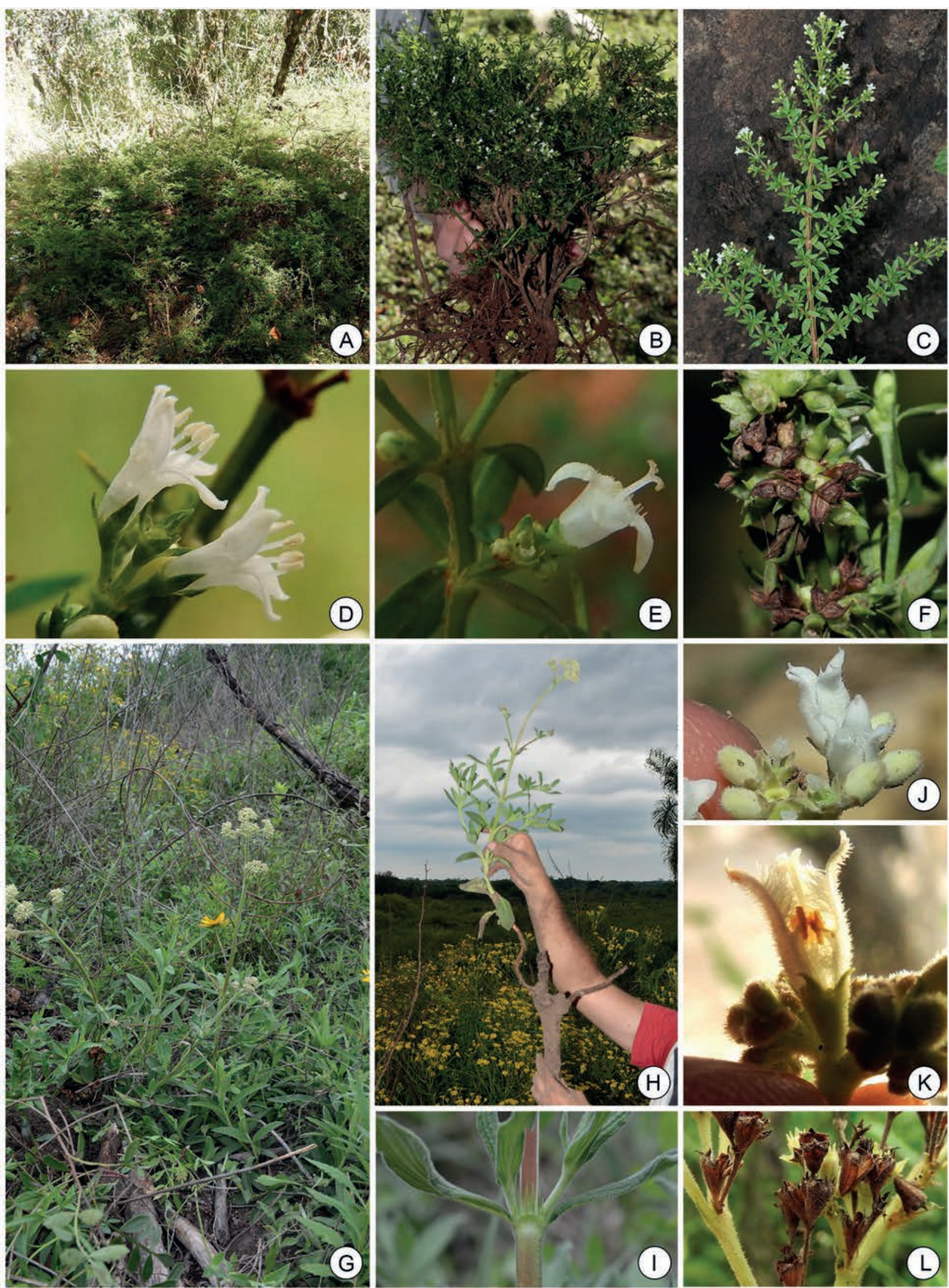

Figure 4. A-F: Galianthe brasiliensis. A: Ambient. B: Habit. C: Detail of the apical portion of a branch. D: Detail of SS flowers. E: Detail of LS flowers. F: Detail of mature and immature fruits. G-L: G. centranthoides. G: Ambient. H: Habit. I: Detail of the stipular sheath. J: Detail of SS flowers. K: Longitudinal section of a LS flower. L: Detail of dehiscent fruits. 
Table 2. Morphological comparison between Galianthe riograndensis sp. nov. and G. equisetoides.

\begin{tabular}{|c|c|c|}
\hline & G. riograndensis & G. equisetoides \\
\hline Number of leaves per node and size (mm) & 3-4 leaves, $30-100 \times 7-13$ & 2-3 leaves, $26.6-49.7 \times 0.5-1.1$ \\
\hline Brachyblasts & Ausent, verticillate leaves & Present, pseudoverticillate leaves \\
\hline Stipular sheath length (mm) & $9-14$ & $3.8-4.7$ \\
\hline Number and length of the fimbriae (mm) & 3-6 fimbriae; 5-7 & 5-6 fimbriae, 2.8-5.6 \\
\hline Leaf shape & Elliptic or narrowly elliptic & Linear or filiform \\
\hline Leaf venation & Visible primary and 2-3 secondary veins & Insconpicuous primary and secondary veins \\
\hline Flower length (mm) & $\begin{array}{l}\text { SS flowers: } 8.5-10 \\
\text { LS flowers: } 8.5-9.6\end{array}$ & $\begin{array}{l}\text { SS flowers: } 5-6 \\
\text { LS flowers: } 4.5-5\end{array}$ \\
\hline Inner corolla indument & $\begin{array}{l}\text { A fringe of moniliform hairs disposed from the middle of } \\
\text { the corolla tube to the lower half of the corolla lobes }\end{array}$ & A ring of moniliform hairs in the corolla tube \\
\hline Style & Divided & Not divided \\
\hline Capsule length (mm) & Capsule 4.5-6 & Capsule 2.2-3.7 \\
\hline Seed length $(\mathrm{mm})$ & Seeds 3-3.5 & Seeds $2.5-3$ \\
\hline Habitat & Hillsides with basaltic rocky fields and seasonal forest & Low and floodable savannas \\
\hline
\end{tabular}

specimens in the past. For this reason, several epithet and subspecific names have been proposed and are currently synonyms of G. centranthoides (Cabral 2009).

Specimens examined: Rio Grande do Sul: Arroio dos Ratos, 28 October 1977, K. Hagelund 11989 (ICN); Caçapava, December 1823, Sellow 1517 (R); Campo Bonito, BR 101, km 6, 10 February 1983, A. Krapovickas et al. 38518 (CTES); Encruzilhada do Sul, Serra dos Pedrosos, 1 December 2012, M. Verdi \& J. A. Jarenkow 6329 (FURB); Fontoura Xavier, 02 July 2011, A. A. Schneider 1700 (ICN); Ipiranga do Sul, BR 153, 27 December 1955, R. A. Wasum 11418 (NY); Idem 14 November 1995, A. Butzke 864 (HUCS); Itapoan, 3 April 1949, B. Rambo 40866 (MO); Lavras do Sul, $58,7 \mathrm{~km} \mathrm{~S}$ de Caçapava do Sul, 11 November 2016, L. P. Queiroz 12376 (HUEFS); Osório, Butiazal, 29 November 2014, F. Gonzatti 1455 (HUCS); Osório, Próximo à Lagoa das Traíras, 29 November 2014, F. Gonzatti 1430 (FURB); Osório, December 1953, R. Vidal 587 (R); Pelotas, s.d., J. da Costa Sacco 693 (NY); Porto Alegre, s.d., M. Sobral et al. 5415 (CTES); Porto Alegre, Morro da Gloria, 3 November 1949, B. Rambo 29388 (ICN); Rio Guaribova, 20 January 1909, P. Dusén 7534 (MO); Santa Maria, 16 April 1985, S. A. Martins 462 (HAS); Santana do Livramento, Cerro Palomas, 14 October 1974, M. L. Porto et al. 1000 (CTES, ICN); São Francisco de Paula, 20 April 2007, H. Lorenzi 5941 (HPL); São Francisco de Paula, Pró-Mata, s.d., C. Mondin s/n (MPUC); Torres, Rod. BR-101, 4km S del acesso a Torres, s.d., A. Krapovickas et al., 44725 (MBM); Vacaria, 10 December 2016, J. E. Florentín et al. 32 (CTES, CTBS).

Galianthe chodatiana (Standl.) E. L. Cabral Bol. Soc. Argent. Bot. 27(34): 242. 1991 [1992]. Fig. 5A-F

(For synonymy and commentaries about the types see Cabral 2009)

Subshrub erect, 0.30-1 m tall, with xylopodium; stem subtetragonal, glabrous. Stipular sheath with a brief extension above the separation of the pair of leaves, 3-5 mm, pilose, with 6-7 fimbriae, glabrous. Leaves pseudoverticillate, with brachyblasts, leaf blades elliptic, 30$45 \times 5-15 \mathrm{~mm}$, discolorous, darker in bundle, abaxial surface pubescent or with scattered hairs on veins, with 3 (4) pairs of secondary veins. Inflorescence thyrsoid terminal only in the main branches, long pedunculate, $20-35 \mathrm{~cm}$. Flowers with hypanthium turbinate, pilose or with scarce scattered hairs; calyx 4-lobed, pilose with intercalary colleters; corolla 4.5-7 mm, externally micropapillate. SS flower with corolla $4.56 .80 \mathrm{~mm}$ long, internally with hairs in base of the corolla lobes and in inferior third of the corolla tube. LS flower with corolla 5-7 $\mathrm{mm}$ long, internally with thick hairs in corolla lobes, and a dense ring of thinner hairs in middle of corolla tube. Capsule $2.5-4.3 \mathrm{~mm}$, glabrous, with dehiscent valves. Seeds 3-3.5 mm long, compressed, with winged edges at poles.

Distribution, habitat, and phenology: Brazil (PR, SC, and $\mathrm{RS}$ ). Frequently found in open grasslands between 700$900 \mathrm{~m}$. Flowering from October and fruiting from January to February.

Observations: Recorded only for the states of Paraná and Santa Catarina, Brazil. From recent collections and study of additional herbarium material, this species is now reported for the first time from the state of Rio Grande do Sul, extending its distribution to southern Brazil.

Specimens examined: Rio Grande do Sul: Barracão, na rodovia para Lagoa Vermelha, 7 February 1988, N. Silveira \& D. Farias filho 5447 (HAS); Esmeralda, 25 November 1983, G. Hiltl. 1454 (CTES, HAS); Vacaria, ruta 116, 28³1'45.94" S 5057'5.15" O, 10 December 2016, J. E. Florentín et. al. 29 (CTES, CTBS).

Galianthe dichasia (Sucre \& Costa) E.L. Cabral, Bol. Soc. Argent. Bot. 27(3-4): 242. 1991. Fig. 5G-K

(For synonymy and commentaries about the types see Cabral \& Bacigalupo 1997)

Subshrub 50-80 cm tall; stems rooting at basal nodes, tetragonal, fistulose, conspicuously winged at each angle, retrorse-fimbriate on margin. Stipular sheath pilose, with 5-7 
fimbriae. Leaves pseudoverticillate, with leafy brachyblasts, leaf blades elliptic, 15-60 × 6-20 mm, pilose, scaberulous or subglabrous on both adaxial and abaxial surfaces, 3-5 pairs of secondary veins. Inflorescense cymose, dichasial to monochasial, with partial inflorescences congested on main and secondary branches. Flowers with obconic, glabrous hypanthium; calyx 4-lobed; corolla externally micropapillate, internally with two rings of moniliform hairs, one in corolla tube and other with thick hairs on base of corolla lobes; SS flower with corolla 4-5.2 $\mathrm{mm}$ long; LS flower with corolla 3-7.5 mm long. Capsule 2.5-3.5 mm long, with indehiscent valves. Seeds $2 \mathrm{~mm}$ long, with strophiole partially covering the ventral surface.

Distribution, habitat, and phenology: Southern Brazil (PR, SC, and RS), Paraguay, Uruguay, and Argentina. This species grows in lowlands, marshy soils, and shore side of inland bodies of freshwater. Flowering from September to May.

Observations: We corroborate that the material recorded and analyzed as Diodia cymosa (Galianthe cymosa) in Rambo (1962) and Porto (1977), corresponds to G. dichasia.

Specimens examined: Rio Grande do Sul: Bom Jesus, 13 January 1941, B. Rambo 8521 (PACA); Cambará do Sul, February 1948, B. Rambo 36712 (PACA); Caxias do Sul, 8 February 1955, B. Rambo 56689 (PACA); Farroupilha, 7 February 1950, B. Rambo 45708 (CTES); idem 14 January 1957, B. Rambo s/n (HAS 71275); Iljuizinho, 30 January 1942, B. Rambo 9961 (PACA); São Leopoldo, 1907, S. Theissen $s / n$ (PACA); Torres, Lagoa dos Quadros, 21 February 1950, B. Rambo 45992 (CTES, LIL).

Galianthe equisetoides (Cham. \& Schltdl.) E.L. Cabral, Bol. Soc. Argent. Bot. 27: 242. 1991. Borreria equisetoides Cham. \& Schltdl. Type: Brazil: Brasilia meridionalis, 18141831, Sellow s.n. [Lectotype here designated: HAL-98351 (photo!)]. Fig. 6A-E.

(For synonymy see Cabral \& Bacigalupo 2009)

Subshrub erect, $0.60-1.50 \mathrm{~m}$ tall, with xylopodium; stems cylindrical or subtetragonal, fistulose, glabrous, constricted at nodes. Stipular sheath glabrous, with 5-6 fimbriae. Leaves 2(-3) pseudoverticillate, with leafy brachyblasts, leaf blades linear or filiform, $15-40 \times 5 \mathrm{~mm}$, glabrous, secondary veins inconspicuous. Inflorescence corymbiform, terminal only on main branches. Flowers with turbinate glabrous hypanthium; calyx 4-lobed, glabrous with intercalar colleters; corolla externally papillate; SS flower with corolla 5-6 $\mathrm{mm}$ long, internally with ring of moniliform hairs in corolla tube; LS flower with corolla $4.5-5 \mathrm{~mm}$ long, internally with ring of thin short moniliform hairs in corolla tube, and ring of thick long hairs in corolla lobes. Capsule 2.2-3.7 mm long, subcylindrical, glabrous, with dehiscent valves. Seeds 2.5-3 mm long, persistent strophiole.

Distribution, habitat and phenology: Brazil (PR and RS), and Argentina. It grows in low and floodable savannas. Flowering from October to February and fruiting from March to June.
Observations: Cabral (2009) designated a neotype for Borreria equisetoides, basonym of this species, assuming that the specimen of Sellow s.n, mentioned in the protologue was deposited in the herbarium B and was destroyed. However, currently the database of JSTOR possesses a digitalized specimen of Sellow s.n deposited in the HAL herbarium, which is here designated as lectotype. It should be noted that this specimen is sterile, nonetheless the stem possesses contractile nodes, linear leaves and inconspicuous secondary veins, all of which are diagnostic characters that diferentiate Galianthe equisetoides.

On the other hand, Abruzzi 1644 (HAS) was incorrectly selected as neotype of the basonym Borreria equisetoides (=G. equisetoides), but because of the 3-4 verticillate leaves, conspicuous secondary veins, larger flowers, long-bifid style, and also by the differences in habitat, the specimen is considered as a paratype of $G$. riograndensis.

Specimens examined: Rio Grande do Sul: Arroio Porto, 08 December 1976, S.T. S. Miotto et al. 165 (ICN); Costa do Cadeia, Triunfo, April 1983, M. Sobral 1657 (BR); Guaíba, 28 October 1970, B. Irgang s/n. (ICN); Guaíba, October 1970, B. Irgang 7834 (ICN); Montenegro, Pareci Novo, 25 November 1945, E. Henz 33227 (CTES, PACA); Montenegro, Prope flumen Cai, 27 December 1949, A. Sehnem 4459 (PACA); Montenegro, Pareci, 25 November 1945, E. Henz s/n (PACA); Porto Alegre, B. Rambo 51549 (PACA); São Pedro do Sul, 27 February 2006, L. P. Deble \& A. S. Oliveira s/ $n$ (HDCF); Tapes, 30 December 1974, M. L. Porto et al. 1378 (ICN); Triunfo, 22 January 1964, E. Pereira 8526 (RB).

Galianthe fastigiata Griseb., Symb. Fl. Argent. 24:157.1879. Fig. 6F-K

(For synonymy and commentaries about the types see Cabral 2009)

Subshrub erect, $0.25-1.20 \mathrm{~m}$ tall, with xylopodium; stems fistulose, cylindrical or subtetragonal, glabrous. Stipular sheath glabrous, with 5-7 fimbriae. Leaves opposite, without axillary brachyblasts, sessile, leaf blades narrowly elliptic or linear, 20-110 × 2-25 mm, glabrous, secondary veins inconspicuous. Inflorescences terminal only on main branch. Flowers sessile or shortly pedunculate; hypanthium turbinate, glabrous; calyx 4-lobed, with intercalar colleters; corolla externally micropapillate; SS flower with corolla 3.5-6.2 mm long, internally with thin moniliform hairs in corolla tube, and thick longer hairs in corolla lobes; LS flower with corolla 3.7-6 mm long, internally with dense hairs, except the lower third of corolla tube. Capsule 3.5-4.5 $\mathrm{mm}$ long, turbinate, glabrous, with dehiscent valves. Seeds 2.5-3.2 mm long, subelliptic, with persistent strophiole; testa scrobiculate.

Distribution, habitat and phenology: Brazil (RS and SC), Argentina, eastern Paraguay and Uruguay. It is common in sandy and rocky soils, in palm groves of Butia and roadsides. Re-grow after burning. Flowering from October to February, fruiting from March to June. 

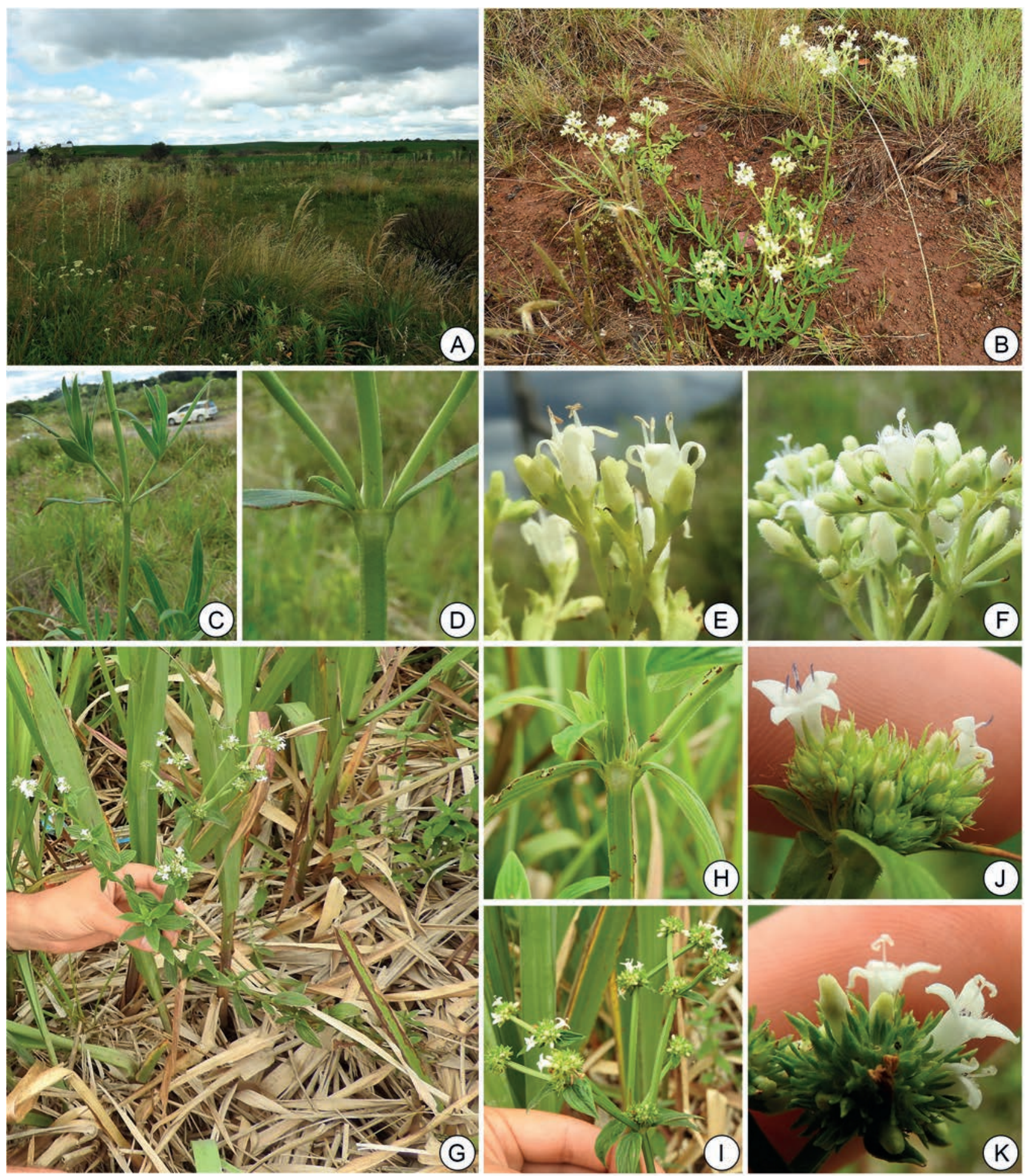

Figure 5. A-F: G. chodatiana. A: Ambient. B: Habit. C: Detail of an internode; note the brachyblasts and stipular sheath. D: Detail of the stipular sheath. E: Detail of SS flowers. F: Detail of LS flowers. G-K: G. dichasia. G: Habit. H: Detail of the stipular sheath. I: Detail of the cymose inflorescence. J: Detail of SS flowers. K: Detail of LS flowers.

Specimens examined: Rio Grande do Sul: Alegrete, BR 290, $40 \mathrm{~km}$ SE de Alegrete, 5 December 1978, A. Krapovickas et al. 34154 (CTES); Alegrete, $10 \mathrm{~km}$ E de Alegrete, BR-290, 18 December 1981, M. M. Arbo et al. 2436 (CTES); Alegrete, Cerro do Tigre, Fazenda Santo Antão, 5 January 2007, E.
Freitas 57 (HVAT); Alegrete, Fazenda Cerro do Tigre, 6 January 2007, J. Spellmeier 123 (ICN); Idem, 25 December 2007, E. Freitas 420 (HVAT); Arroio dos Ratos, 9 December 1983, K. Hagelund 14801 (CTES, ICN); Caçapava do Sul, 28 December 1974, M. Porto et al. 1328 (CTES, ICN); 74 km 
S de Caçapava do Sul, 7 December 1978, A. Krapovickas et al. 34214 (CTES); Cachoeira, Malme 1824 (R); Cachoeira, s/d., Malme 1824 (R); Cachoeira do Sul, km 144 Pantano Grande-, , 27 December 1974, M. Porto et al. 1287 (CTES, FLOR, ICN); Cachoeirinha, 7 January 1949, B. Rambo $s / n$ (PACA); Candiota, Mina da CRM, 22 February 2006, $R$. Wasum et al. 3526 (HUCS); Canguçú, 4 February 2004, F. J. Caporal s/n (ICN); Camaquã, Piratini, 2 December 2012, M. Verdi \& J. A. Jarenkow 6382 (FURB); Canguçu, s/d., F. J. Caporal s/n (ICN); Canoas, 28 January 1948, Palacios et al. 286 (CTES); Capão do Leão, Pedreira do DEPREC, s/d., E. N. Garcia et al. 248 (MBM); Caxias do Sul, Vila Seca, 12 January 2000, L. Scur 392 (FUEL, HUCS, MBM, NY); Idem, 12 January 2000, A. Kegler 546 (HUCS, MBM); Caxias do Sul, Vila Oliva, 13 January 2000, L. Scur 355 (HUCS); Idem, s/d., A. Kegler 546 (MBM); Caxias do Sul, Sta. Lúcia do Piaí, 14 January 2003, L. Scur 1044 (HUCS); Idem, s/d., Scur 1056 (HUCS); Caxias do Sul, Sítio do Vô Anito, 11 December 2005, F. Marchett 466 (HUCS); Caxias do Sul, Vila Seca, 27 February 2005, F. Marchett 116 (HUCS); Encruzilhada do Sul, 12 February 1948, M. Palacios-Cuezzo 1318 (CTES); Esteio, 1 June 1949, B. Rambo s/n (PACA); Giruá para Santa Rosa, 18 April 1974, M. Porto et al. 1153 (CTES, ICN); Guaíba, Fazenda São Maximiano BR 116 Km 308, 31 January 2006, L. F. Lima 255 (ICN); Jaquirana, 20 February 1952, B. Rambo 52052 (B); Lavras do Sul, 21 January 1994, A. Krapovickas et al. 44664 (CTES); Lavras do Sul-Rincão do Inferno, 29 December 1974, M. Porto et al. 1347 (CTES, ICN); Lagoa Vermelha, 8 February 2012, M. Verdi 6115 (JOI, FURB, HVAT); Lagoa Vermelha, Boqueirão, 8 January 2012, M. Verdi 6115 (JOI); Montenegro, 19 July 1977, Ungaretti 446 (HAS); Muitos Capões, Lajeado Bonito, 10 February 2012, M. Verdi \& B. O. Boeni 6166 (FURB); Pantano Grande, km 127, BR 37 entre Pantano Grande e Caçapava do Sul, 30 October 1961, G. Pabs et al. 6423 (UB); Pelotas, 23 January 1950, I. Egydio 2 (MO); Idem, 10 March 1956, Schlichting s/n (PACA); Piratini, Serra das Asperezas, s/d., J. A. Jarenkow 1426 (MBM); Piratini, Fazenda Pedra Grande, s/d., A. Guglieri et al. 711 (ICN); Piratini, Fazenda Pedra Grande, 5 October 2005, A. Guglieri et al. 658 (ICN); Porto Alegre, Morro Santa, s/d., M. M. Marchi s/n (ICN); Porto Alegre, Vila Manresa, 3 March 1950, B. Rambo s/n (PACA); Porto Alegre, Morro Santana, 31 January 1985, M. Sobral 3719 (INPA); Porto Alegre, Morro São Pedro Econsciência Espaço de Conservação, 20 October 2005, R. Setubal 146 (ICN); Idem, 29 October 2005, R. Setubal 570 (HUCS); Porto Alegre, Rio dos Sinos, 10 December 1948, B. Rambo 38661 (CTES); Porto Alegre, Morro Santana, 31 January 1985, M. Sobral et al. 3719 (SP); Porto Alegre, Morro Santana, 10 December 1979, Z. Soares 233 (UEC); Porto Alegre, Morro Teresópolis, 29 January 1980, Z. Soares 265 (CTES, HAS); Porto Alegre, Morro da Policia, 18 January 1964, E. Pereira et al. 30819 (B); Porto Alegre, Teresópolis, 14 March 1949, B. Rambo 40482 (SP); Santa Maria, Reserva Biológica do Ibicuí-Mirim, 19 June 1991, N. Silveira 8689 (CTES, HAS);
$25 \mathrm{~km}$ N de Santana da Boa Vista, 12 November 2006, L. P. de Queiroz, 12410 (HUEFS); Santiago, 5 April 1975, M. Porto et al. 1421 (CTES, ICN); Santiago para S. F. de Assis, 5 April 1975, M. Porto et al. 1433 (CTES, ICN); 70 km de São Borja, 21 January 1983, A. Krapovickas et al. 38381 (CTES); São Borja, s/d., F. Baglione 1942 (PACA); São Francisco de Paula, 18 km E, 10 January 1982, A. Krapovickas et al. 37637 (CTES); Sao Francisco de Paula, Lajeado Grande, 11 January 2002, R.A. Wasum 1305 (NY); São Francisco de Paula, Lajeado Grande, 11 January 2002, R. A. Wasum 1305 (NY); São Gabriel, 39 km de S. Gabriel, 20 January 1973, A. Krapovickas et al. 22838 (CTES); São Leopoldo, Morro Sapucaia, 03 February 1956, B. Rambo 59164 (HBR); São Leopoldo, Morro Sapucaia, 3 February 1956, B. Rambo 59164 (HBR); São Sepé $1 \mathrm{~km}$ al este do entroncamento da BR-290 com a BR-392, 25 November 2005, M. Machado 615 (HUEFS); Sapucaia do Sul, 17 October 1949, B. Rambo (PACA); Serra Santana, Cerro Grande, 16 December 1996, J. A. Jarenkow s/n (CRI); Sertão Santana, próximo da Rod. BR-116, s/d., J. A. Jarenkow 3315 (MBM); Soledade, s.d, B. Rambo 50047 (B); Taquari, 12 December 1957, O. R. Camargo 2905 (PACA); Taquari, 10 December 1957, O. R. Camargo 3016 (PACA); Vacaria, 28³1'45.94" S 5057'5.15" O, 10 December 2016, J.E. Florentin et al. 30 (CTES, CTBS); Vacaria, 23 January 1969, V. Pott 463 (IBGE); Viamão, Prox. Parque Saint Hilaire, 31 August 2012, F. Schmidt Silveira 209 (ICN); Viamão, Morro da pedreira, 7 March 1980, Z. Soares 289 (EAC); Viamão, Lago Tarumã, 23 October 2008, P. J. Silva Filho 726 (ICN); Villa Oliva, s/d., B. Rambo 56661 (B).

Galianthe hispidula (A. Rich. ex DC.) E. L. Cabral \& Bacigalupo, Ann. Missouri Bot. Gard. 84(4): 870-871. 1997. Fig. 7A-F

(For synonymy and commentaries about the types see Cabral \& Bacigalupo 1997)

Subshrub with long stolons, $30-60 \mathrm{~cm}$ tall; decumbent stems; and simple flowering branches tetragonal, winged, glabrous or pilose on the angles. Stipular sheath scabridulous or pilose, with 5-9 fimbriae. Leaves opposite, pseudopetiolate, leaf blades elliptic, 35-100×15-35 mm, discolorous, with 5-8 pairs of slightly-curved subparallel secondary veins. Inflorescences cymose, monochasial to pleiochasial, partial inflorescences fasciculate and congested, terminal on main and secondary branches. Flowers with turbinate hypanthium; calyx 4-lobed, with 2 large lobes; corolla externally micropapillate; SS flower with corolla 2.9$4.64 \mathrm{~mm}$ long, internally with sparse hairs in corolla tube and at base of corolla lobes; LS flower with corolla 3.24-4.26 $\mathrm{mm}$ long, internally with thick moniliform hairs in corolla lobes, and thin hairs in corolla tube. Capsule 1.6-2 mm long, subhemispheric, scabridulous or glabrous, with indehiscent valves. Seeds 1.4-1.6 mm long, with persistent strophiole.

Distribution, habitat, and phenology: Brazil (MG, PR, RJ, SC, SP, and RS), eastern Paraguay and northeastern Argentina. Grows in understory with abundant litterfall 

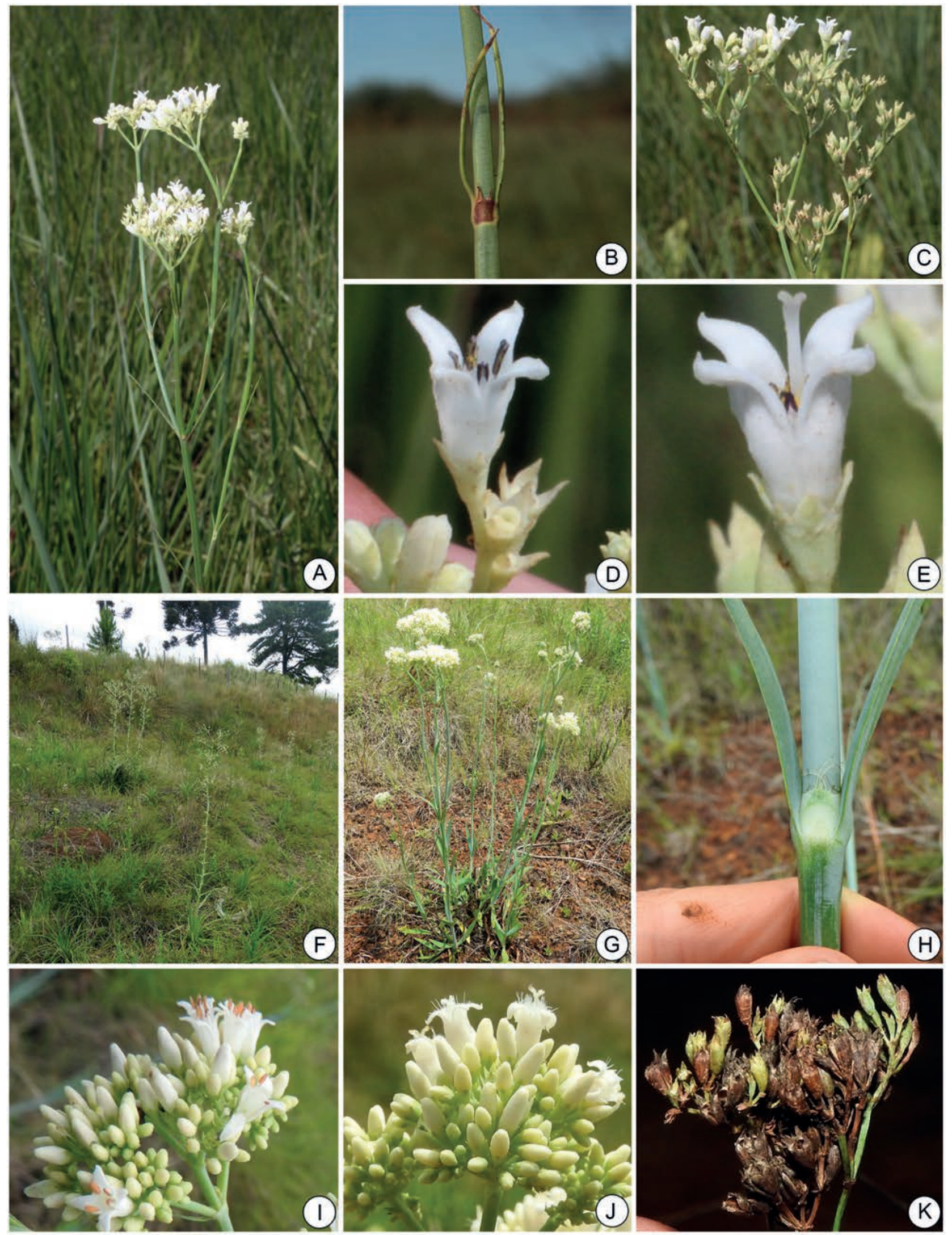

Figure 6: A-E: G. equisetoides. A: Habit. B: Detail of the stipular sheath. C: Apical portion of the plant, with inflorescences. D: Detail of a SS flower. E: Detail of a LS flower. F-K: G. fastigiata. F: Ambient. G: Habit. H: Detail of the stipular sheath. I: Detail of SS flowers. J: Detail of LS flowers. K: Detail of fruits. 
and in drained soils. Flowering and fruiting from September to May.

Specimens examined: Rio Grande do Sul: Camaquã, Arroio Sutil, 9 July 1974, M. L. Porto 856 (ICN); Derrubadas, Parque Estadual do Turvo, 17 January 2005, C. D. Inácio 50 (PACA); Idem, 29 May 2004, C. D. Inácio 7 (ICN); Derrubadas, Reserva Florestal do Turvo, 22 November 1975, M. L. Porto et al. 1910 (CTES, ICN); Morrinhos do Sul, Morro Azul, s/d., J. A. Jarenkow 3279 (CRI); Nonoai, Reserva Nonoai, 7 December 1974, M. L. Porto 1186 (CTES, ICN).

Galianthe latistipula E.L. Cabral, Bonplandia 6(4):14-18. 1993. Fig. 7G-J

(For synonymy and commentaries about the types see Cabral 2009)

Subshrub erect, 45-95 cm tall, with xilopodium; 1(2-3) stems per plant, without lateral branches, stems fistulose, cylindrical or subtetragonal, glabrous. Stipular sheath extended above insertion of leaves, irregular margin with remarkable central fimbria, triangular, acuminate, and shorter lateral fimbriae. Leaves 6-10 pseudoverticillate, with leafy brachyblasts, sessile, leaf blades lanceolate, ellipticlanceolate, 15-60 × 3-15 mm, glabrous, inconspicuous secondary veins on adaxial surface, slightly marked on the abaxial surface. Inflorescence corymbiform, terminal only on main branches. Flowers with turbinate hypanthium, glabrous; calyx 4-lobed, with intercalar colleters; corolla externally glabrous; SS and LS flowers with similar corolla size. Capsule 2.5-3.5 mm long, turbinate, glabrous, with dehiscent valves. Seeds 2-2.7 mm long, compressed, with slightly alate apex, with a caducous strophiole.

Distribution, habitat, and phenology: Brazil (RS and SC). This species lives in high rocky fields between 1000-1800 $\mathrm{m}$ elevation in the Meridional high plateau (Fernandes \& Bezerra 1990), also called "Planalto riograndense" (Rambo 1956). Flowering and fruiting from December to March.

Specimens examined: Rio Grande do Sul: Bom Jesus, 5 January 1947, B. Rambo 34859 (PACA, SI); Bom Jesus, Itaimbezinho, 5 January 1978, S. T. S. Miotto 794 (ICN); Carazinho, 27 January 1957, I. Januário s/n (ICN); Criúva, Caxias do Sul, 20 January 1999, A. Kegler 90 (HUCS); Fundo Feio, 28 February 1964, A. Schultz 3990 (ICN); Jaquirana, Faz Rodeio Velho, 19 March 2006, R. Wasum 3614 (HUCS); Lagoa Vermelha, January 1943, B. Rambo 11408 (PACA); Lavras do Sul, Ibaré, 7 February 1996, R. Robert et al. 6 (MO); Nonoai, ad fl. Uruguay, 1 March 1945, B. Rambo s/n (PACA); Nonoai, March 1945, B. Rambo 28228 (PACA); Passo do Inferno, 9 January 1955, B. Rambo 56578 (CTES, PACA); Idem, 1 Mach1965, Brescia \& Marchesi 4089 (MVFA); Passo do Inferno, Canela, 9 January 1955, B. Rambo s/ $n$ (PACA); São Francisco de Paula, pr. Jaquirana, 20 February 1952, B. Rambo 52052 (B); Soledad, 13 February 1951, B. Rambo 50047 (B, CTES, LIL, PACA); Próximo a Tainhas, 12 February 1987, N. Silveira 3824 (CTES, HAS); Vacaria, 15 January 1942, B. Rambo 8763 (PACA); Vacaria e Lagoa Vermelha BR
$285 \mathrm{Km}$ 25, s/d., S. T. S. Miotto 805 (ICN); Vila Oliva, Caxias do Sul, 12 January 2000, L. Scur 383 (HUCS, FUEL, MBM, MO); Idem, 12 January 2000, A. Kegler 538 (MBM, NY).

Galianthe laxa (Cham. \& Schltdl.) E. L. Cabral, Bol. Soc. Argent. Bot. 27: 244-245. 1991. Fig. 8A-E

(For synonymy and commentaries about the types see Cabral 2009)

Subshrub scandent $0.5-1.7 \mathrm{~m}$ tall, without xylopodium; stems tetragonal glabrous, puberulous or pubescent. Stipular sheath pubescent, with 5-12 fimbriae. Leaves pseudoverticillate, with leafy brachyblasts, pseudopeciollate, leaf blades elliptic or oval-elliptic, 20-100 × 6-30 mm, discolorous, glabrous or with sparse hairs on adaxial surface and pubescent on abaxial surface, with 4-6 pairs of secondary veins arched towards apex, furrowed in adaxial surface, and prominent in abaxial surface. Inflorescences thyrsoid, lax, rarely compressed. Flowers, with turbinate hypanthium, glabrous, puberulous or pubescent; calyx 4-lobed, with intercalar colleters; corolla externally papillate; SS flower with corolla 3-4 mm long, internally with a fringe of thin moniliform hairs in corolla tube; LS flower with corolla 2.7$4 \mathrm{~mm}$ long, internally with ring of short thin moniliform hairs in middle of corolla tube, and ring of thick hairs in middle of corolla lobes. Capsule 1.7-3 mm long, turbinate, glabrous or with sparse hairs, with dehiscent valves. Seeds 1.7-2.5 mm long, elliptic, with caducous strophiole, rarely persistent; testa foveolate.

Distribution, habitat, and phenology: Brazil (MS, PR, RS, SC, and SP), eastern Paraguay, Bolivia, Argentina, and Uruguay. It is one of the most widely distributed species, occurring between $16^{\circ}$ and $25^{\circ} \mathrm{S}$. It lives at different elevations in low fields, on the banks of streams and rivers, in open places or inside forests. Along with Galianthe brasiliensis, they are the two southernmost species, reaching the delta of Parana, Buenos Aires. Flowering from November to February and fruiting from March to August.

Observations: Galianthe laxa is represented in Rio Grande do Sul by the subsp. laxa. This subspecies is highly variable in habit, indumentum, form, size and texture of leaves, development and size of inflorescences.

Specimens examined: Rio Grande do Sul: Bom Retiro do Sul, 12 December 2012, G. B. Scherer s/n (HVAT); Boqueirão do Leão, 29 December 2001, E. Burloni s/n (HUCS); Caxias do Sul, São Nicolau, 12 February 2000, L. Scur 462 (FUEL, HUCS); Caxias do Sul, Vila Seca, 1 February 2000, A. Kegler 594 (MBM, HUCS); Idem, 9 January 2003, L. Scur 997 (HUCS); Caxias do Sul, Hotel Samoara, em orla de capoeira, 18 December 1999, L. Scur 333 (FUEL); Faxinal, Ana Rech, 13 February 2003, L. Scur 1080 (HUCS); Idem, 26 February 1999, L. Scur 24 (HUCS, FUEL); Gramado, 20 March 1950, B. Rambo 46408 (CTES); Iraí, Balneário Osvaldo Cruz, 23 January 1990, A. Krapovickas et al. 43486 (CTES); Marcelino Ramos, Estreito R. Uruguai, 10 January 1996, A. Butzke et al. s/n (HUCS); Marcelino Ramos, Rio Uruguai, , s/d., J. A. 

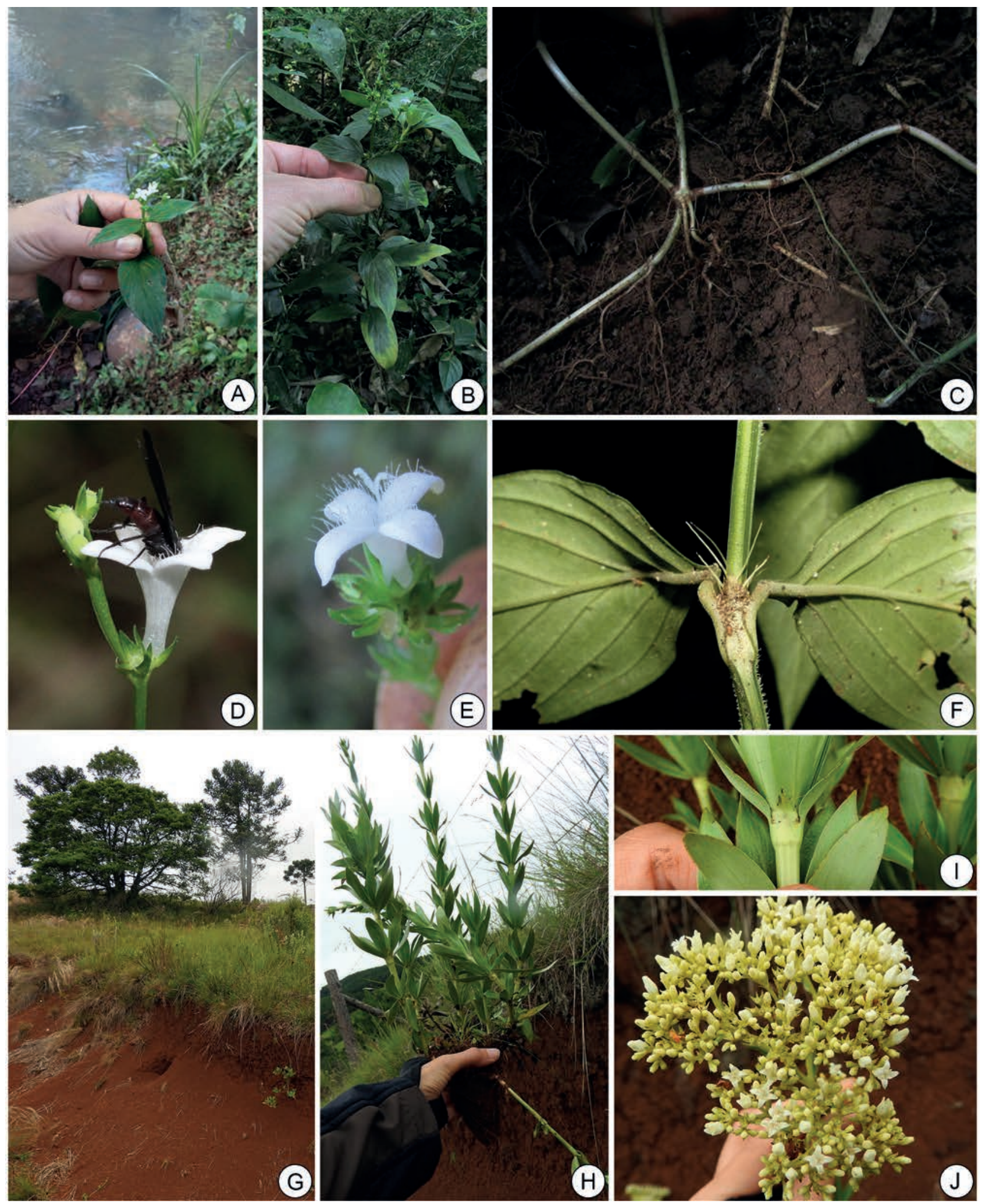

Figure 7: AF: Galianthe hispidula. A: Ambient. B: Habit. C: Details of the stolons. D: Detail of a flower with a pollinator. E: Detail of a LS flower. F: Detail of the stipular sheath. G-J: G. latistipula. G: Ambient. H: Habit. I: Detail of the stipular sheath. J: Detail of an inflorescence. 
Jarenkow 1620 (MBM); Morrinho de Porto Fagundes, Dom Pedro de Alcantara, 28 February 2009, C. Modin s/ $n$ (MPUC); Nova Prata- Cascata da Usina, 2 March 1989, R. A. Wasum 5336 (NY); São Francisco de Paula, Linhas S. Paulo, 5 March 2000, R. Wasum 497 (HUCS); São Francisco de Paula, RS235, 25 March 2001, R. Wasum 1019 (HUCS); Torres, 30 March 1977, L. Buselato 19 (HAS); Idem, 19 July 1974, M. L. Porto 890 (CTES, ICN);Viamão, Aguas Claras, Banhado dos Pachecos, 5 December 2012, F. Schemidt-Silveira 412 (ICN);

Galianthe thalictroides (K. Schum.) E.L. Cabral. Bol. Soc. Argent. Bot. 27(3-4): 246. 1991. Fig. 8F-K

(For synonymy and commentaries about the types see Cabral 2009)

Subshrub erect, branched, 0.6-1.2 m tall, with 3-5 main branches with numerous opposite and secondary branches, xylopodium well-developed; often forms dense scrubs; stems subtetragonal, glabrous or papillate. Stipular sheath glabrous or puberulous, with 1-5 fimbriae. Leaves pseudoverticillate, with brachyblasts, leaf blades linear or narrowly elliptic, $8-25 \times 7-2 \mathrm{~mm}$, margin revolute, glabrous or papillate, conspicuous primary veins and inconspicuous secondary veins. Inflorescences thyrse corymbiform, pedunculated, terminal only on main branch. Flowers with turbinate hypanthium, glaborus; calyx 4-lobed, glabrous, with intercalary colleters; corolla externally papillate; SS flower with corolla 5.5-6.2 mm long, internally with ring of moniliform hairs in corolla tube, and sparse hairs in corolla lobes; LS flower with corolla 3.7-5 mm long, internally with ring of thin moniliform hairs in corolla tube, and thick hairs in corolla lobes. Capsule 3-5 mm long, with dehiscent valves. Seeds $2-3.5 \mathrm{~mm}$ long, dorsoventrally compressed, irregularly winged, ventral surface partially covered by strophiole.

Distribution, habitat and phenology: Brazil (RS, SC, PR, and SP), northeast Argentina, eastern Paraguay and Uruguay. This species grows in highland grasslands, lateritic soils, modified lands, roadsides. Flowering from November to January and fruiting from February to March.

Specimens examined: Rio Grande do Sul: Caçapava do Sul, 28 December 1974, M. L. Porto 1332 (ICN); Granja Sodal, February 1964, K. Hagelund 1408 (ICN); Giruá, 18 April 1974, M. L Porto et al. 1154 (ICN); Ijuí, 8 January 1957, B. Rambo 60307 (PACA); Ijuí, São Bernardo, 8 January 1957, B. Rambo s/n (PACA); Ipiranga do Sul, BR-153, 27 December 1995, A. Butzke et al. s/n (HUCS); Idem, 27 December 1995, R. Wasum et al. s/n (HUCS); Santo Ângelo, Granja Piratini, 9 December 1976, S. Miotto 237 (ICN).

Galianthe valerianoides (Cham. \& Schltdl.) E. L. Cabral, Bol. Soc. Argent. Bot. 27(3-4): 246-247. 1991. Fig. 9A-G

(For synonymy and commentaries about the types see Cabral 2009)

Subshrub erect, 0.8-2.5 m tall, with xylopodium; stems tetragonal, fistulose, scabrous, rarely glabrous, angles with retrorse hairs. Stipular sheath pubescent, with 9-11 fimbriae. Leaves pseudoverticillate, with brachyblasts, leaf blades narrowly elliptic or oblong, 35-115 x 10-25 mm, plicate-nervose, scabridous, with 4-6 pairs of subparallel veins. Inflorescence terminal on main branch. Flower with micropapillate hypanthium, sometimes pilose; calyx 4-lobed, papillate, intercalar colleters; corolla externally papillate; SS flower with corolla $3.4-4.5 \mathrm{~mm}$ long, internally a fringe of moniliform hairs in corolla tube and in base of the corolla lobes; LS flower internally with ring of thin short moniliform hairs in corolla tube, and thicker longer hairs in corolla lobes. Capsule 3.7-4.2 mm long, subcylindrical, glabrous, sometimes with sparse hairs, with dehiscent valves. Seeds 2.5-3.5 mm long, dorsoventrally compressed, unequally winged, wings larger at the ends; testa finely foveolate

Distribution, habitat, and phenology: Brazil (DF, GO, MS, MG, PR, RS, SC, and SP), northeast Argentina, eastern Paraguay. It lives in swamps, low places, and marshes and streams. Flowering from October to January, and fruiting from February to July.

Specimens examined: Rio Grande do Sul: Bom Jesus, 4 December 1971, J. Lindeman $s / n$ (ICN 9460); Caixas do Sul, Vila Oliva, 8 February 1955, B. Rambo 53473 (PACA); Canela, February 1986, M. Sobral et al. 4939 (CTES, ICN); Ipiranga do Sul, BR-153, 27 December 1995, R. Wasum et al. s/n (HUCS); Santo Ângelo, January 1932, G. Jürgens 460 (B); São Francisco de Paula, Várzea do Cedro, s/d., $R$. Wasum 834 (MBM); São Francisco de Paula, Taimbesinho, 12 February 1956, B. Rambo 58564 (B, PACA); Serra do Fachinal, 21 February 1951, B. Rambo 50139 (B, CTES); Torres, Itapeva, 14 November 1957, A. Schultz s/n (ICN 4517); Vacaria, Passo do Socorro, 26 December 1951, B. Rambo 51549 (PACA); Vasconcelos, 22 February 1967, E. Duarte 10397 (RB).

Galianthe verbenoides (Cham. \& Schltdl.) Griseb., Symb. Fl.Argent. 24:157. 1879. (For synonymy and commentaries about the types see Cabral 2009)

Subshrub erect, branched, 0.6-1 m tall, with opposite lateral branches well-developed, without xylopodium; stems tetragonal or subcylindrical, glabrous, sometimes with hairs or aculeate or mammillate papillae near stipular sheath. Stipular sheath glabrescent or pubescent, with 1011 fimbriae. Leaves pseudoverticillate, with brachyblast pseudopeciolate, leaf blades oblong-elliptic, 15-120 ×3$17 \mathrm{~mm}$, discolorous, glabrescent or scabridulous, abaxial surface with aculeate papillae of thick base on the veins, especially on primary vein, with 3-6 pairs of secondary veins subopposite, in converging arcs toward apex. Inflorescences thyrsoid, terminal on main and secondary branches. Flowers with turbinate hypanthium, glabrous; calyx 4-lobed, glabrous, with intercallar colleters; corolla externally micropapillate; SS flower with corolla (2.5) $4.5-4.7 \mathrm{~mm}$ long, internally with ring of moniliform hairs in middle of corolla tube; LS flower with corolla 3-3.2 mm long, internally 

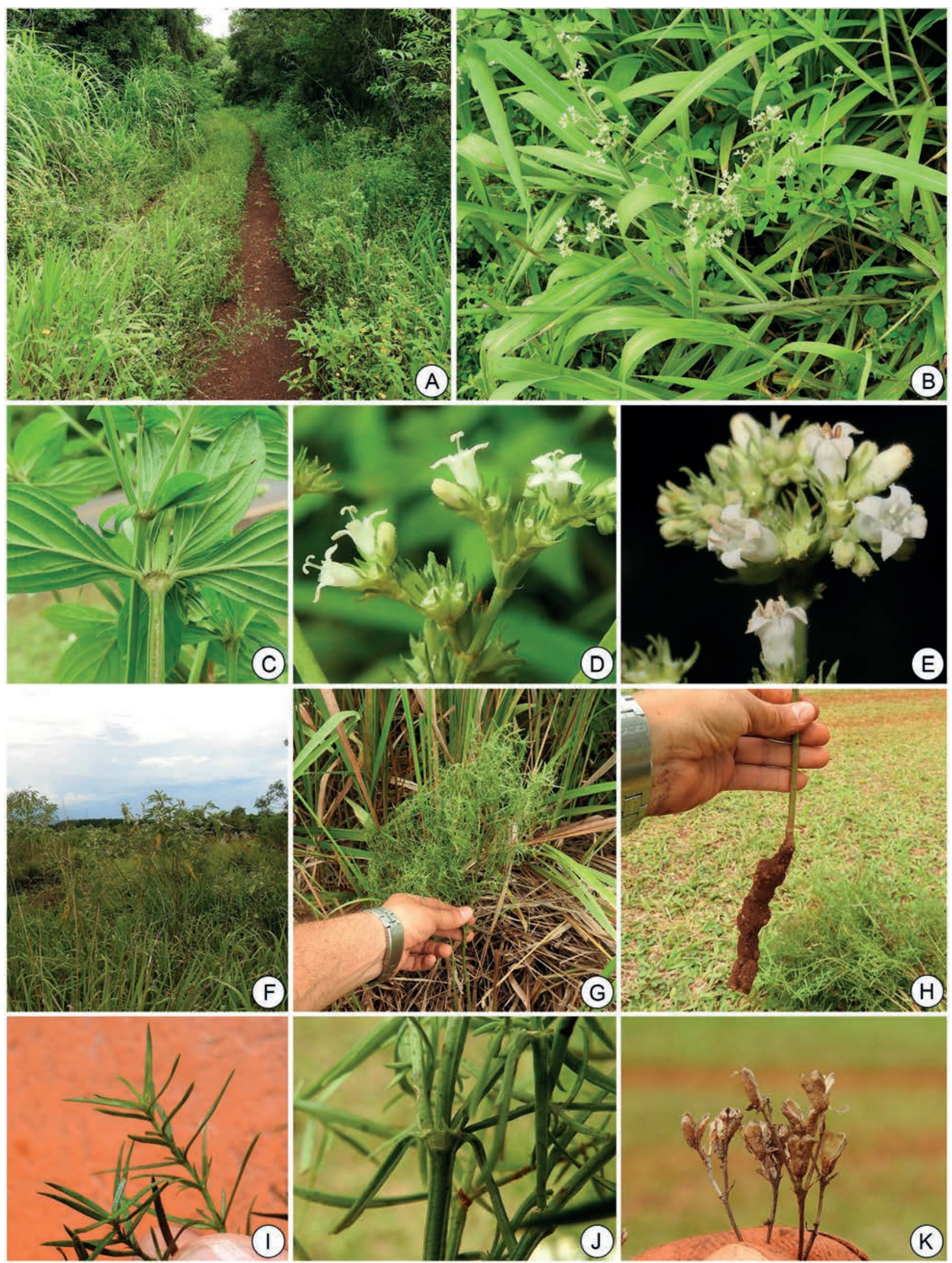

Figure 8. A-E: G. laxa. A: Ambient. B: Habit. C: Detail of the stipular sheath and the abaxial surface of the leaf. D: Detail of LS flowers. E: Detail of SS flowers F-K: G. thalictroides. F: Ambient. G: Habit. H: Detail of a portion of the stem and xylopodioum. I: Portion of a branch. J: Detail of the stipular sheath. K: Detail of the dehiscent fruits. 

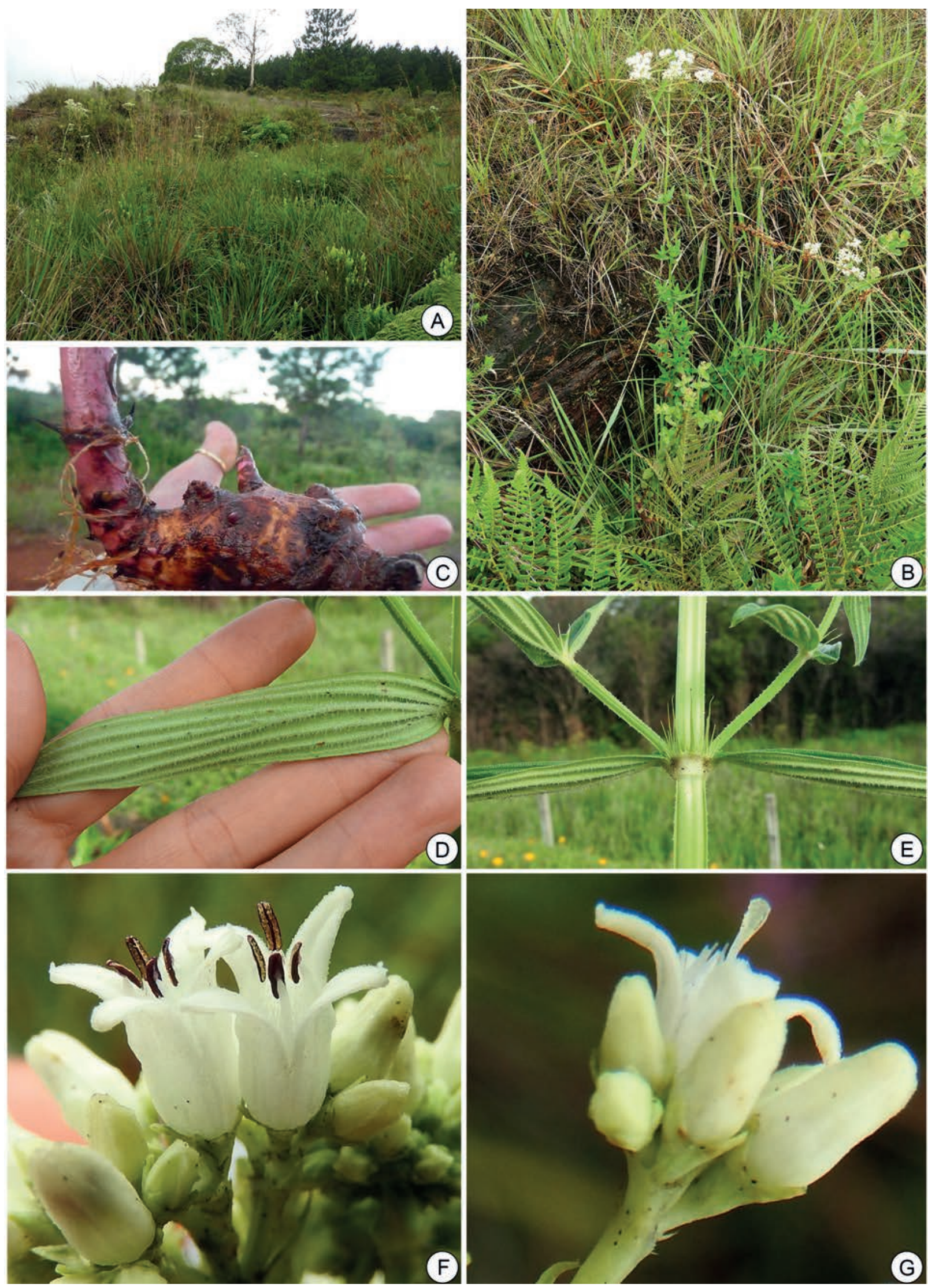

Figure 9. A-G: G. valerianoides. A: Ambient. B: Habit. C: Detail of the xylopodium. D: Detail of the abaxial surface of leaves. E: Detail of node, showing the leaves, brachyblasts, and stipular sheath. F: Detail of SS flowers. G: Detail of LS flowers. 
with short moniliform hairs in middle of corolla tube, and sparse hairs in base of the corolla lobes. Capsule 1.7-2 mm long, subglobose, glabrous, with dehiscent valves. Seeds 1.5-1.7 mm long, subcylindrical, strophiole persistent; testa scrobiculate.

Distribution, habitat, and phenology: Brazil (PR, RS, and $\mathrm{SC}$ ). It is very common in roadsides, edges of streams, and in highlands. Flowering and fruiting from November to April.

Specimens examined: Rio Grande do Sul: Arroio dos Ratos, 30 January 1985, E. Cabral 486 (CTES); Bom Jesus, 14 January 1942, B. Rambo 8690 (PACA); Bom Jesus, Serra da Rocinha, s/d., B. Rambo 53850 (MBM); Caxias do Sul, Criúva, Palanquinhos, 18 November 2014, F. Gonzatti 1360 (HUCS); Caxias do Sul, Vila Oliva, 08 November 2006, B. Rambo s/n (PACA); Caixas do Sul, February 1945, Buck 28042 (LIL); Cambará do Sul, Fortaleza, 1994, I. A. dos Santos s/n (MPUC); Cambará do Sul, Itaimbezinho, 11 March 1988, N. Silveira 7314 (HAS); Cambará do Sul, Itaimbezinho, s/d., D. B. Falkenberg 6006 (MBM); Cambará do Sul, Itaimbezinho, s/d., J. A. Jarenkow 1168 (MBM); Canela, February 1986, Sobral et al. s/n (CTES); Canela, Caracol, 08/XI/2006, K. Emrich s/n (PACA); Dois Irmãos, 27 January 1983, O. Bueno et al. 17897 (CTES); Gramado, 25 December 1949, B. Rambo 44966 (CTES); Gravataí, 18 October 1977, Ungaretti 1818 (HAS); Gravataí, M. Morungava, acesso nos km 21 e 22 a esquerda da RS 020 no sentido Gravataí-Taquara, 28 July 1996, $O$. Bueno 1234 (SP); Lajeado Grande, 26 November 2010, P. A. Ferreira 452 (ICN); Lavras do Sul, Rincão do Inferno, 1991, C. Schlindewein $s / n$ (MPUC); Lavras do Sul, 29 December 1974, M.L. Porto et al. 1346 (CTES, ICN); Montenegro, 26 December 1935, B. Rambo 2233 (LIL, PACA); Pareci Novo, 21 November 1945, Sehnem 1489 (LIL, SI); Passo Fundo, 5 January 1982, A. Krapovickas et al. 37579 (CTES); Porto Alegre, ad flumen Caí inferius, 8 November 2006, B. Rambo $s / n$ (PACA); Porto Alegre, Morro da Polícia, 20 November 2008, R. Setubal \& P. Ferreira 968 (ICN); Santa Cruz do Sul, 26 December 1946, Sehnem 2388 (SI); São Francisco de Paula, 1998, B. Harter s/n (MPUC); Idem, 21 March 2005, H. Bertz $s / n$ (MPUC); São Francisco de Paula, Rio das Antas, 28 July 2014, P. J. Silva Filho 2055 (ICN); São Francisco de Paula, 26 January 1969, Körner 57332 (ICN); São José dos Ausentes, Aparados da Roscinha, 18 January 1950, B. Rambo 45393 (CTES); São Sebastião do Caí, 27 April 1949, B. Rambo 41243 (CTES); Soledade, 8 December 1976, Fleig 197 (ICN); Soledade, Rod. BR-386, próximo ao Arroio Tatim, s/d., J. A. Jarenkow 3340 (MBM); Torres, arredores de Itapeva, 17 January 2014, F. Gonzatti 1032 (FURB).

\section{Acknowledgements}

We thank Laila Miguel and Roberto Salas for their valuable suggestions and help with taxonomic issues; and Laura Simón for preparing the illustrations. Also we would like to thank José Floriano Pastore and Michelle Mota for their hospitality during our stay in Brazil and for their assistance on the field trip in Rio Grande do Sul, Santa Catarina and Paraná. Also, we thank to Consejo Nacional de Investigaciones Científicas y Tecnológicas (CONICET), for the grants awarded that supported this work.

\section{References}

Bachman S, Bachman S, Moat J, Hill AW, Torre J, Scott B. 2011. Supporting red list threat assessments with GeoCAT: Geospatial conservation assessment tool. In: Smithand V, Penev L. (eds.) e-Infrastructures for data publishing in biodiversity science. ZooKeys 150. Richmond, Kew Botanic Gardens. p. 117-126.

Cabral EL. 2002. Revisión del género Galianthe Griseb. (Rubiaceae). PhD Thesis, Universidad Nacional del Nordeste, Corrientes.

Cabral EL. 2009. Revisión Sinóptica de Galianthe subgen. Galianthe (Rubiaceae: Spermacoceae), con una sección nueva. Annals of the Missouri Botanical Garden 96: 27-60.

Cabral EL, Bacigalupo N. 1997. Revisión del género Galianthe subg. Ebelia stat. nov. (Rubiaceae-Spermacoceae). Annals of the Missouri Botanical Garden 83: 857-877.

Carmo MAJ, Salas R, Simões AO. 2016. An updated description of Galianthe vaginata (Spermacoceae, Rubiaceae), a species endemic to the Serra da Mantiqueira and Serra do Mar, Southeast Brazil. Phytotaxa 258: 089094.

Erdtman G. 1966. Pollen morphology and Plant Taxonomy Angiosperm. An introduction to Palynology I. New York and London, Hatner Publishing Company.

Fernandes A, Bezerra P. 1990. Estudo fitogeográfico do Brasil. Fortaleza, Stylus Comunicações.

Flora do Brasil 2020 em construção. Galianthe. Rio de Janeiro, Jardim Botânico do Rio de Janeiro. http://floradobrasil.jbrj.gov.br/reflora/ floradobrasil/FB14000. March 2017.

Google Earth. 2015. http://www.google earth.com.ar. May 2016.

Hijmans RJ. 2013. DIVA-GIS, a geographic information system for the analysis of biodiversity data. Version 7.5. http://www.diva.gis.org. March 2016.

Iganci JR, Heiden G, Miotto STS, Pennington RT. 2011. Campos de Cima da Serra: the Brazilian Subtropical Highland Grasslands show an unexpected level of plant endemism. Botanical Journal of the Linnean Society 167: 378-393.

IUCN. 2001. IUCN Red List Categories. Gland, Switzerland, Cambridge, IUCN.

Kårehed J, Groeninckx I, Dessein S, Motley TJ, Bremer B. 2008. The phylogenetic utility of chloroplast and nuclear DNA markers and the phylogeny of the Rubiaceae tribe Spermacoceae. Molecular Phylogenetics and Evolution 49: 843-866.

Leite PF. 2002. Contribuição ao conhecimento fitoecológico do Sul do Brasil. Ciência \& Ambiente 24: 5173.

Porto ML, Jacques SMC, Miotto ST, Waechter JL, Detoni ML. 1977. Tribo Spermacoceae-Rubiaceae I. Flora Ilustrada Río Grande do Sul 35: 82-85.

Punt WS, Hoen PP, Blackmore S, Nilsson S, Le Thomas A. 2007. Glossary of pollen and spore terminology. Review of Palaeobotany and Palynology 143: 181.

Rambo B. 1956. A flora fanerogâmica dos Aparados riograndenses. Sellowia 7/8: 235-298.

Rambo B. 1962. Rubiaceae riograndenses. Pesquisas, série Botânica 18: 1-76.

Salas RM, Viana PL, Cabral EL, Dessein S, Janssens S. 2015. Carajasia (Rubiaceae), a new and endangered genus from Carajás mountain range, Pará, Brazil. Phytotaxa 206: 14-29.

Stearn WT. 1986. Botanical Latin. 3rd. edn. London, David \& Charles Publishers.

Thiers B. 2017. Index herbariorum: a global directory of public herbaria and associated staff. New York Botanical Garden's Virtual Herbarium. http://sciweb.nybg.org/science2/IndexHerbariorum.asp. 10 Mar. 2017. 